\title{
Structural insights into the functional versatility of an FHA domain protein in mycobacterial signaling
}

\author{
Tristan Wagner ${ }^{1 a^{*}}$, Gwenaëlle André-Leroux ${ }^{1 b^{*}}$, Valérie Hindie ${ }^{1 \mathrm{c}}$, Nathalie Barilone ${ }^{1 \mathrm{~d}}$, \\ María-Natalia Lisa ${ }^{1 e}$, Sylviane $\operatorname{Hoos}^{2}$, Bertrand Raynal ${ }^{2}$, Brigitte Vulliez-Le \\ Normand $^{1}$, Helen M. O’Hare ${ }^{3}$, Marco Bellinzoni ${ }^{1 \uparrow}$ \& Pedro M. Alzari ${ }^{1 \uparrow}$
}

${ }^{1}$ Institut Pasteur, Unité de Microbiologie Structurale, CNRS UMR 3528 \& Université Paris Diderot, 25 rue du Docteur Roux, 75724 Paris cedex 15, France; ${ }^{2}$ Institut Pasteur, Plateforme de Biophysique Moléculaire, 25 rue du Docteur Roux, 75724 Paris cedex 15, France; ${ }^{3}$ Leicester Tuberculosis Research Group (LTBRG) and Leicester Institute of Structural and Chemical Biology (LISCB), Department of Respiratory Science \& Department of Molecular and Cell Biology, University of Leicester, Leicester LE1 7RH, UK.

* These authors contributed equally to this work.

` Corresponding authors. Email: pedro.alzari@pasteur.fr (PMA) and marco.bellinzoni@pasteur.fr (MB)

\section{Current addresses:}

${ }^{a}$ T.W., Max Planck Institute for Marine Microbiology, Microbial Metabolism group, Celsiusstrasse 1, D-28359 Bremen, Germany.

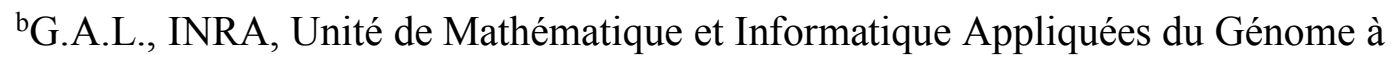
l'Environnement, Université Paris-Saclay, 78350 Jouy-en-Josas Cedex, France.

'V.H., Caprion Biosciences Inc., 201 ave. President Kennedy, Montreal, Canada H2X 3Y7.

${ }^{\mathrm{d} N}$.B., Unité Récepteurs-Canaux, Institut Pasteur, 75724 Paris cedex 15, France.

eM.N.L., Instituto de Biología Molecular y Celular de Rosario (IBR, CONICET-UNR), Ocampo y Esmeralda, S2002LRK Rosario, Argentina. 


\section{ABSTRACT}

Forkhead-associated (FHA) domains are modules that bind phosphothreonine (pThr) residues in signaling cascades. The FHA-containing mycobacterial protein GarA is a central element of a phosphorylation-dependent signaling pathway that redirects metabolic flux in response to amino acid starvation or cell growth requirements. GarA acts as a phosphorylation-dependent ON/OFF molecular switch. In its unphosphorylated ON state, the GarA FHA domain engages in phosphorylation-independent interactions with various metabolic enzymes that orchestrate nitrogen flow, such as 2-oxoglutarate decarboxylase (KGD). However, phosphorylation at the GarA amino-terminal region by the protein kinases $\mathrm{PknB}$ or $\mathrm{PknG}$ triggers the intramolecular association with its own FHA domain, thus blocking all downstream interactions. To investigate these different FHA binding modes, we solved the crystal structures of the mycobacterial upstream (phosphorylation-dependent) complex PknB-GarA and the downstream (phosphorylation-independent) complex GarA-KGD. Our results show that the phosphorylated activation loop of PknB serves as a docking site to recruit GarA through canonical FHA-pThr interactions. However, the same GarA FHA binding pocket targets an allosteric site on unphosphorylated KGD, where a key element of recognition is a phosphomimetic aspartate. Further enzymatic and mutagenesis studies revealed that GarA acted as a dynamic allosteric inhibitor of KGD by preventing crucial motions in KGD that are necessary for catalysis. Our results provide strong evidence for physiological phosphomimetics, supporting numerous mutagenesis studies using such approaches, and illustrate how evolution can shape a single FHA binding pocket to specifically interact with multiple phosphorylated and non-phosphorylated protein partners. 


\section{INTRODUCTION}

Reversible serine-threonine protein phosphorylation mediated by Hanks-type serine-threonine protein kinases (STPKs) and phosphatases has emerged as a major regulatory mechanism in bacteria (1-3). As shown by extensive studies in eukaryotic cells, phosphorylation at serine, threonine, and tyrosine residues can directly alter the biochemical function of a protein, but more often it creates new docking sites for phosphorylation-dependent binding partners (4). This supports the idea that phosphorylation-based signal transduction systems can be thought of as tripartite toolkits composed of protein kinases acting as 'writers', protein phosphatases as 'erasers', and phospho-binding domains as downstream 'readers' of the posttranslational modification (5). Since the discovery of Src homology 2 (SH2) domains (6), which specifically bind phosphotyrosine residues, many different types of reader domains have been described in eukaryotic cell signalling. The current list of known modules that specifically bind to phosphoserine (pSer) and phosphothreonine (pThr) residues includes no less than 14 unrelated domain types (5). Remarkably, however, in bacteria the widespread distribution of STPKs contrasts with the finding that only one of those reader protein modules has so far been found, namely the Forkhead-associated (FHA) domain (7).

First identified within the forkhead family of transcription factors (8), FHA domains serve as adaptor modules that specifically recognize pThr-containing proteins and mediate proteinprotein interactions that are driven by reversible phosphorylation of many eukaryotic regulatory proteins with roles in the DNA damage response, checkpoint signaling pathways, cell growth, and cell cycle regulation (9). FHA modules share a conserved fold consisting of a 10- or 11stranded $\beta$-barrel that contains the pThr-binding pocket at one of the apical surfaces $(10,11)$. The atomic structures of over 50 FHA domains are currently available, and the majority of these were determined either in the absence of a cognate binding partner or by using a phosphopeptide 
to represent the binding partner. This strategy is apparently justified by structures in which the target pThr recognized by the FHA lies in an unstructured N- or C-terminal region (12-14). Notably, some FHA domains bind non-phosphorylated protein partners using surfaces distinct from the pThr-binding pocket. This may occur in FHA domains that lack the conserved phosphate-interacting residues, such as that of kinesin KIF13 (15), or that use their canonical pThr-binding site to interact with a third protein partner, such as the FHA1 domain of Rad51 (16).

In prokaryotes, FHA domain-containing proteins are ubiquitous in three main phyla, namely Actinobacteria, Cyanobacteria, and selected Gram-negative Proteobacteria (7), but their precise roles in bacterial physiology are generally not well characterized. We focused on GarA, member of an Actinobacterial-restricted family of FHA domain-containing proteins that play a central role in the kinase-mediated control of glutamate metabolism $(17,18)$. Mycobacterial GarA was initially described as a glycogen accumulation regulator (hence its name) in Mycobacterium smegmatis (19) and identified as an optimal substrate of the serine-threonine protein kinase PknB in Mycobacterium tuberculosis protein extracts (20). Subsequently, it was characterized as a key regulator of glutamate metabolism in M. tuberculosis, M. smegmatis (13, 18, 21, 22), and Corynebacterium glutamicum, wherein the GarA orthologue was named OdhI for 2-oxoglutarate dehydrogenase inhibitor $(23,24)$. GarA is essential to sustain M. tuberculosis growth and viability, but it is dispensable in M. smegmatis and C. glutamicum, where disruption of the garA or $o d h I$ genes, respectively, caused a distinctive, nutrient-dependent phenotype (23, 25).

GarA protein family members are small proteins ( $~ 160$ amino acids) consisting of a C-terminal FHA domain linked to an unstructured N-terminal extension of 40-50 residues that includes a 
consensus phosphorylation motif ETTSVFR (Fig. 1A and fig. S1). GarA is a key element of a conserved STPK-mediated signaling pathway that controls glutamate metabolism (Fig. 1B). Unphosphorylated GarA was shown to activate the glutamate synthase (GS) complex (13) and to inhibit the activities of E1o, the first component of the 2-oxoglutarate dehydrogenase (ODH) multiprotein complex, and GDH, a NAD-dependent glutamate dehydrogenase (18) in mycobacteria. Although only the interaction of the GarA homologue OdhI with E1o has been reported in C. glutamicum (23), the net outcome of the unphosphorylated OdhI activity is the same as for GarA, namely a redirection of the metabolic flux towards the synthesis of glutamate (Fig. 1B). In response to nutrient availability or cell growth requirements (22), phosphorylation at the first or second Thr residue within the ETTSVFR motif, respectively by STPKs PknG or PknB (Fig. 1B), triggers its intramolecular association with the C-terminal FHA domain, switching off the modulatory interactions with downstream metabolic enzymes $(12,13,26)$. Therefore, at different stages of the signaling pathway (Fig. 1B) GarA acts as either a specific STPK protein substrate, a phosphorylation-dependent molecular ON/OFF switch, or an allosteric metabolic modulator. Quite unusually, GarA performs all these tasks by using its FHA domain to specifically recognize upstream pThr-containing proteins and downstream nonphosphorylated protein partners. In order to gather structural insights into this intriguing functional versatility, we report here structural and biochemical studies of the upstream (phosphorylation-dependent) signaling complex PknB-GarA, and the downstream (phosphorylation-independent) effector complex GarA-E1o. These studies revealed that the phosphorylated activation loop of PknB serves as a docking platform for the recruitment of the FHA domain-containing protein substrate, and that GarA allosterically inhibits E1o by precluding protein motions required for catalysis. Altogether, these observations illustrate how a canonical FHA domain binding pocket can be fine-tuned to specifically interact with both phosphorylated as well as non-phosphorylated protein partners, clearly extending the actual 
functions of prokaryotic FHA domain proteins beyond a simple role of phosphorylation 'reader' domains, with important implications for bacterial cell signaling.

\section{RESULTS}

\section{The phospho-dependent signaling complex PknB-GarA}

In previous work we showed that M. tuberculosis GarA is an efficient substrate of various STPKs, mainly PknB and PknG $(18,20)$. Phosphorylation occurs at $\mathrm{Thr}^{21}(\mathrm{PknG})$ or $\mathrm{Thr}^{22}$ $(\mathrm{PknB})$ in the disordered $\mathrm{N}$-terminal extension of GarA, requiring in both cases specific docking interactions between phosphorylated residues in the kinase and the substrate's FHA domain. The auto-phosphorylated docking sites in PknG are located outside the catalytic domain (18), but those in $\mathrm{PknB}$ (pThr ${ }^{171}$ and $\mathrm{pThr}^{173}$ ) are both in the kinase activation loop (20) and their interaction with the GarA FHA domain would thus be expected to sequester the activation loop away from the active kinase conformation (27). To address this intriguing issue, we sought to characterize the structure of $M$. tuberculosis GarA in complex with the catalytic domain (residues 1-279) of wild-type PknB (hereafter referred to as $\mathrm{PknB}_{\mathrm{CD}}$ ). The autophosphorylated $\mathrm{PknB}_{\mathrm{CD}}-\mathrm{Gar} \mathrm{A}$ interaction was observed in solution (fig. S2) with a dissociation constant $\left(K_{D}\right)$ in the micromolar range (fig. S3). Upon extensive crystallization trials, however, all the crystals we obtained contained $\mathrm{PknB}_{\mathrm{CD}}$ in a 'back-to-back' homodimer conformation $(28,29)$ with no bound GarA. The reported $K_{D}$ for dimerization is high $(2.9 \mathrm{mM})(30)$, suggesting that dimerization of $\mathrm{PknB}_{\mathrm{CD}}$ in different crystal forms (28-31) may result from the high protein concentrations used for crystallization. To explore whether kinase dimerization could exclude GarA-binding, we produced a monomeric form of $\mathrm{PknB}_{\mathrm{CD}}$ using the point mutation $\mathrm{Leu}^{33}$ to glutamic acid ( $\left.\mathrm{PknB}_{\mathrm{CD}, \mathrm{L} 33 \mathrm{E}}\right)$ that abrogated $\mathrm{PknB}$ dimerization (30) but retained wild-type-like phosphorylation activity on GarA (see next section). This monomeric form of PknB was 
successfully crystallized in complex with GarA and AMP-PCP, a non-hydrolysable ATP analog, and the crystal structure of the ternary complex was determined at $2.3 \AA$ resolution (Table 1).

The crystal structure contained two molecules of the ternary complex in the asymmetric unit and revealed that the FHA domain of GarA interacted primarily with the phosphorylated activation loop of PknB (Fig. 2A). Despite using a non-hydrolysable ATP analogue, no electron density was visible for the ETTSVFR peptide substrate (GarA residues 20-26) in the kinase active site. Indeed, the entire N-terminal extension of GarA, residues 1-45, was mostly disordered in the crystal structure, in agreement with the high flexibility observed for this region in the NMR structures of unphosphorylated M. tuberculosis GarA and C. glutamicum OdhI (12, 13). The only exception was a short peptide fragment (corresponding to GarA residues 26-34) that was clearly visible in the electron density map for one of the two independent complexes, between helix $\alpha \mathrm{G}$ in PknB and a positively charged region of the FHA domain of GarA (Fig. 2A and Fig. 2B). This position would be compatible with GarA $\operatorname{Thr}^{22}$ reaching the kinase active site, because the same peptide fragment occupies a similar position against the FHA domain core in the NMR structures of phosphorylated GarA and OdhI (fig. S4).

\section{A canonical phosphate-binding pocket in the FHA domain}

The phosphorylated activation loop, which was systematically disordered in other PknB crystal structures (28-31), now exhibited an extended conformation at the PknB-GarA interface (Fig. 2A). The observed conformation, positioning the phosphate groups of $\mathrm{pThr}^{171}$ and $\mathrm{pThr}^{173}$ far (>10 A) from the guanidinium group of the HRD motif, differentiates PknB from eukaryotic kinases that require interaction between HRD and $\mathrm{pThr}$ for activation. The loop follows a path across the surface of the FHA domain that is similar to that previously observed in other FHA 
domain-phosphopeptide complex structures (fig. S5). The phosphate-binding site of the FHA domain, mainly defined by the loops between strands $\beta 4-\beta 5$ and $\beta 6-\beta 7$ (fig. S6), binds pThr ${ }^{171}$ from the PknB activation loop (Fig. 2C). The phosphate group is stabilized by intermolecular hydrogen bonding interactions with several GarA residues: the guanidinium groups of $\mathrm{Arg}^{81}$ and $\mathrm{Arg}^{96}$, the hydroxyl group of $\mathrm{Ser}^{95}$ and the main chain nitrogen atom of $\mathrm{Arg}^{96}$. Additional H-bonds are formed between the phosphopeptide backbone adjacent to $\mathrm{pThr}^{171}$ in the kinase and the side chains of $\mathrm{Arg}^{81}$ and $\mathrm{Asn}^{117}$ in the FHA domain. All these interactions involve residues from three conserved motifs in bacterial FHA domains (7), namely $G^{80} R$ at the Cterminus of strand $\beta 3, S^{95} \mathrm{RxH}$ just preceding $\beta 5$, and motif $\mathrm{S}^{115} \mathrm{xNG}$ in the turn $\beta 6-\beta 7$ (fig. $\mathrm{S} 1$ ), indicating a 'canonical' mode of pThr recognition.

Uniquely amongst FHA-pThr complexes, however, an additional structural element directly interacts with the phosphorylated residue. The guanidinium group of $\operatorname{Arg}^{58}$ on $\mathrm{PknB}$ helix $\alpha \mathrm{C}$ makes a strong salt bridge with $\mathrm{pThr}^{171}$ (Fig. 2C), promoting major structural changes in the helix (see next section). Additionally, the total $\mathrm{PknB}_{\mathrm{CD}}-\mathrm{Gar} \mathrm{A}$ interface of $1100 \AA^{2}$ (including the N-terminal GarA peptide 26-34) is higher than those typically observed for FHAphosphopeptide complexes. The additional contacts are primarily mediated by the positively charged region formed by the loops $\beta 1-\beta 2$ and $\beta 9-\beta 10$ in the FHA domain of GarA that interact with the C-terminus of the PknB activation loop, preceding helix $\alpha \mathrm{E}$, and with helix $\alpha \mathrm{G}$ through the N-terminal GarA peptide (Fig. 2B).

Upon binding of the GarA FHA domain, the PknB regulatory helix $\alpha \mathrm{C}$ moves away from the conformation observed in the back-to-back PknB homodimer (28). The helical axis is displaced $6 \AA$ towards the core of the PknB N-lobe and the helix undergoes partial unwinding at its Cterminus (Fig. 2D). As a consequence, the overall conformation of the kinase N-lobe in complex 
with GarA appears to be incompatible with that observed in the PknB homodimer, possibly accounting for our unsuccessful attempts to crystallize the complex between GarA and wildtype $\mathrm{PknB} \mathrm{BD}_{\mathrm{CD}}$. Furthermore, these GarA-induced changes in helix $\alpha \mathrm{C}$ weaken a well-conserved intramolecular salt bridge in the kinase domain whose integrity is usually important for activity because it positions the $\alpha$ - and $\beta$-phosphate groups of ATP correctly for catalysis (32). This bridge between $\mathrm{Lys}^{40}$ and $\mathrm{Glu}^{59}$ from helix $\alpha \mathrm{C}$ is $4.2 \AA$ in the $\mathrm{PknB} \mathrm{CD}_{-}-$GarA complex, compared to $2.8 \AA$ in homodimeric $\mathrm{PknB}_{\mathrm{CD}}$. Similar conformational changes have been described for two $\mathrm{PknB}_{\mathrm{CD}}$ point mutants (30), suggesting a high conformational plasticity of the active kinase.

\section{The kinase activation loop as a docking site for FHA-mediated substrate recruitment}

To determine the effects of the observed conformational changes on kinase activity, we measured the phosphorylation activity of $\mathrm{PknB}_{\mathrm{CD}}$ towards full-length GarA compared to that towards an N-terminal GarA peptide, which contained the phosphorylation site but lacked the FHA domain. The activities of the point mutant $\mathrm{PknB}$ CD,L33E on both substrates were roughly equivalent to those of wild-type $\mathrm{PknB}_{\mathrm{CD}}$ on the same substrates (Fig. 2E), confirming that the amino acid substitution L33E had no major effect on the kinase activity under the assayed conditions. In contrast, the two versions of $\mathrm{PknB}_{\mathrm{CD}}$ were both markedly less active toward the GarA-derived peptide substrate compared to full length GarA (Fig. 2E), indicating that GarA phosphorylation is strongly dependent on the interaction between the kinase activation loop and the FHA domain. An important question here is whether the phosphorylated activation loop is acting as a passive docking platform for substrate recruitment (with no increase of the intrinsic kinase activity) or, alternatively, whether FHA domain binding has an allosteric effect on the kinase activity. To elucidate this issue, we produced a GarA deletion mutant that comprises only the FHA domain but is devoid of the N-terminal phosphorylatable extension, and assayed the kinase activity of $\mathrm{PknB}_{\mathrm{CD}}$ on the peptide substrate in the presence or absence of this mutant. 
The addition of FHA failed to increase (it even slightly decreased) the intrinsic kinase activity of $\mathrm{PknB}_{\mathrm{CD}}$ or $\mathrm{PknB}_{\mathrm{CD}, \mathrm{L} 33 \mathrm{E}}$ towards the peptide substrate (Fig. $2 \mathrm{~F}$ ), indicating that the FHA domain of GarA does not function as an allosteric kinase activator. Taken together, the above crystallographic and enzymatic results therefore imply that, in the case of GarA, the phosphorylated activation loop of $\mathrm{PknB}$ serves as a docking (phospho)site for substrate recruitment.

\section{The downstream phospho-independent complex GarA-ODH}

In Actinobacteria, the catalytic domains of components E1o (2-oxoglutarate dehydrogenase) and E2o (dihydrolipoamide succinyl transferase) of the ODH complex (homologues to E. coli SucA and SucB, respectively) are encoded in a single polypeptide, named OdhA in Corynebacteriaceae (33) and KGD in Mycobacteriaceae (34). E1o (SucA) is a thiamin diphosphate-dependent enzyme that, in addition to its 2-oxoglutarate dehydrogenase activity (EC 1.2.4.2) as part of the ODH complex, also exhibits 2-oxoglutarate decarboxylase (EC 4.1.1.71) and 2-oxoglutarate:glyoxylate carboligase (EC 2.2.1.5) activities (21, 34-36). In previous work, we characterized the crystal structure of $M$. smegmatis $\operatorname{KGD}(21,37)$ and demonstrated that GarA inhibited the E1o domain, corresponding to KGD residues 361-1227 $\left(\mathrm{KGD}_{\Delta 360)}\right.$ (21). To gain insight into the mode of phospho-independent recognition and inhibition of KGD we crystallized $\mathrm{KGD}_{\triangle 360}$ in complex with the FHA domain of GarA $\left(\right.$ GarA $\left._{\Delta 44}\right)$ (Table 1). M. smegmatis proteins were used but we maintained M. tuberculosis residue numbering for GarA to allow comparison with the $\mathrm{PknB}_{\mathrm{CD}}-\mathrm{Gar} \mathrm{A}$ complex (the two mycobacterial GarA homologues are 95\% identical, see fig. S1, including all residues involved in protein-protein interactions). 
The FHA domain of GarA binds to the $\mathrm{KGD}_{\triangle 360}$ homodimer with a 2:2 stoichiometry (Fig. 3A). FHA binding promoted no major conformational changes in $\mathrm{KGD}_{\Delta 360}$, because the overall RMSD between the holo (PDB code 2YIC) and FHA-bound structures of wild-type $\mathrm{KGD}_{\triangle 360}$ was $0.43 \AA$ for $811 \mathrm{C} \alpha$ atoms. Also, the structure of the M. smegmatis FHA domain was structurally identical to that of the PknB-bound M. tuberculosis FHA domain, with an overall RMSD of $0.3 \AA$ for 90 equivalent $\mathrm{C} \alpha$ atoms. The apical binding surface of the FHA domain is in contact with a strand-connecting loop (residues 586-594) and two outer $\alpha$-helices (residues 475-500 and 785-813) of KGD, $\sim 30 \AA$ away from the catalytic center. The protein-protein interaction buries $\sim 2000 \AA^{2}$ of the molecular surfaces, and is stabilized through hydrophobic and polar contacts, including several intermolecular salt bridges and hydrogen bonding interactions (Fig. 3B). Partially mimicking a phosphorylated residue, the Asp ${ }^{795}$ carboxylate from KGD outer helix 785-813 occupies the phosphate-binding pocket of the FHA domain (Fig. 3C), where it makes a hydrogen-bonding interaction with the hydroxyl group of GarA Ser ${ }^{95}$, a crucial pThr-interacting residue. Two other side chains from the same KGD helix, $\mathrm{Arg}^{794}$ and $\mathrm{Gln}^{799}$, are H-bonded to the backbone carbonyls of GarA residues Gly ${ }^{114}$ and $\mathrm{Val}^{92}$, respectively, and further stabilize the observed orientation of the helix across the pThr-binding pocket. On the other half of the interface, the KGD loop 586-594 is tightly held in place through several hydrogen bonding interactions of its backbone carbonyl groups with the guanidinium groups of residues $\mathrm{Arg}^{62}$ and $\mathrm{Arg}^{143}$ from the FHA domain (Fig. 3D).

The observed KGD-GarA interface is similar to a model proposed for the homologue OdhAOdhI complex from C. glutamicum (38) and can account for OdhA-OdhI crosslinking experiments reported in that study. To further validate the observed interface, we produced three KGD surface mutants: (1) the charged residue $\mathrm{Asp}^{795}$ that mimics the phosphorylated residue was substituted by alanine, (2) two residues involved in the interface, $\mathrm{Ser}^{484}$ and $\mathrm{Ala}^{488}$, 
were substituted by arginine and glutamine, respectively, in order to prevent formation of a stable complex by adding two bulky side chains, and (3) the basic residue $\operatorname{Arg}^{802}$, engaged in an intermolecular salt bridge, was substituted by alanine. These mutants retained wild-type decarboxylase activity but differed in their interaction with GarA. Mutants $\mathrm{KGD}_{\triangle 360, \mathrm{D} 795 \mathrm{~A}}$ and $\mathrm{KGD}_{\triangle 360, \mathrm{~S} 484 \mathrm{R}, \mathrm{A} 488 \mathrm{Q}}$ were not inhibited by GarA, even at high concentrations (Fig. 3E), likely because the mutations precluded FHA binding. These results highlight the functional importance of the phosphomimetic $\mathrm{Asp}^{795}$ carboxylate and the primary role of the FHA phosphate-binding pocket in phospho-independent KGD recognition. In contrast, $\mathrm{KGD}_{\triangle 360, \mathrm{R} 802 \mathrm{~A}}$ was more efficiently inhibited by GarA (Fig. 3E) than the wild-type enzyme. The inhibition constant $K_{i}$ was displaced from $2.5 \mu \mathrm{M}$ for wild-type $\mathrm{KGD}_{\Delta 360}$ to $0.4 \mu \mathrm{M}$ for $\mathrm{KGD}_{\triangle 360, \mathrm{R} 802 \mathrm{~A}}$. The crystal structure of this KGD point mutant in complex with GarA (Table 1) revealed that the absence of the $\operatorname{Arg}^{802}$ side chain allowed a tighter fitting of the KGD helix 785-813 against the GarA phosphate-binding pocket, thus optimizing protein-protein interactions that compensate for the loss of the intermolecular salt bridge. In agreement with this observation, $C$. glutamicum OdhA has a small side chain (serine) at the equivalent position of KGD $\operatorname{Arg}^{802}$ and is more efficiently inhibited by OdhI (23), with a $K_{i} 100$-fold lower than that of GarA for KGD in M. smegmatis.

\section{Dynamic allosteric inhibition of the 2-oxoglutarate dehydrogenase}

GarA binding to a distal region does not block substrate access to the active site, nor does it promote structural changes in KGD. What then is the mode of action of GarA as a KGD inhibitor? Our previous structural and mutagenesis studies of mycobacterial $\operatorname{KGD}(21,37)$ revealed that formation of the post-decarboxylation covalent reaction intermediate triggered important conformational changes, most notably a global rearrangement of the active-site environment that creates a binding funnel for the acceptor substrate(s). These concerted protein 
motions promote the transition from a basal resting state of KGD to a fully active state (39), and are intimately linked to a $\sim 4 \AA$ shift of a surface-exposed $\alpha$-helix (residues $785-813$ ). It is precisely this $\alpha$-helix that lies at the center of the GarA-binding interface and contains the phospho-mimetic residue Asp $^{795}$ (Fig. 3A). Therefore, formation of the GarA-KGD complex locks the enzyme in its basal resting state by blocking the helical movement and the ensuing structural transition.

Our structural studies of KGD had shown that formation of the post-decarboxylation covalent intermediate can be achieved in the initial resting conformation, before the structural transition occurs (37), and therefore should not be affected by GarA binding. To further investigate this hypothesis, we soaked crystals of the $\mathrm{KGD}_{\Delta 360, \mathrm{R} 802 \mathrm{~A}}-\mathrm{Gar}_{\Delta 44}$ complex for long times in 2oxoglutarate. The crystal structure, refined at $2.4 \AA$ resolution (Table 1), showed no major conformational changes in the active site, indicating that the structural transition had not taken place. However, the post-decarboxylation covalent intermediate derived from 2-oxoglutarate was clearly visible in the electron density maps (fig. S7), demonstrating that GarA binding did not prevent the first reaction step. These results further confirm our proposed inhibition mechanism based on blocking protein motions, and are consistent with previous circular dichroism studies of M. tuberculosis KGD indicating that GarA inhibited the second half of the enzymatic reaction (39).

Moreover, GarA would be expected to have a differential effect on the reported KGD catalytic activities. By stabilizing the basal conformation of KGD, GarA binding precludes formation of the acceptor substrate-binding sites for the lipoyl and the glyoxylate groups needed to complete the dehydrogenase and carboligase reactions, respectively. In contrast, the semi-aldehyde species in the decarboxylation reaction is generated by direct proton attack to the post- 
decarboxylation covalent intermediate, and should therefore be less affected by GarA. In agreement with this model, at $5 \mu \mathrm{M}$ concentration GarA efficiently inhibited the dehydrogenase reaction (no ODH activity could be detected), but did not totally abolish the decarboxylase reaction, because a residual succinic-semialdehyde production $(\sim 27 \%$ of the value in the absence of GarA) was measured for $\mathrm{KGD}_{\Delta 360}$ under the same conditions (40). Taken together, the above results demonstrate that unphosphorylated GarA modulates KGD activity through a dynamic allosteric inhibition mechanism.

\section{Structural basis of FHA-protein interactions}

The structures of the phosphorylation-dependent (upstream) and phosphorylation-independent (downstream) GarA complexes described above revealed that, despite the considerable differences in the target proteins, the FHA domain retained its structural integrity and engaged essentially the same molecular surface for protein binding. In the two protein complexes, the interface included the FHA phosphate-binding pocket, defined by the C-terminus of strand $\beta 3$ and the loops $\beta 4-\beta 5$ and $\beta 6-\beta 7$, and a shallow adjacent cleft of positively charged residues from loops $\beta 1-\beta 2$ and $\beta 10-\beta 11$. As shown by NMR studies of the autoinhibited closed form of GarA (13), this same interface was also used for self-recognition of $\mathrm{pThr}^{22}$ (Fig. 4). The dual binding specificity of GarA towards phosphorylated and non-phosphorylated proteins is intriguing. Guided by the available structures, we performed surface plasmon resonance experiments to explore the effect of four M. smegmatis GarA mutations within the common interface: one involving a central pThr-binding residue, Ser ${ }^{95}$, and three others involving positively charged residues from the adjacent region, $\operatorname{Arg}^{62}$, Lys ${ }^{141}$ and $\operatorname{Arg}^{143}$ (Fig. 2 and Fig. 3). 
Our structures and mutational studies underscore the importance of $\mathrm{PknB} \mathrm{pThr}^{171}$ interaction within the GarA phosphate-binding pocket as a primary determinant of PknB binding, whereas the interactions of KGD Asp ${ }^{795}$ mimicking pThr are essential for KGD binding. Mutation of the conserved GarA Ser ${ }^{95}$ in the phosphate-binding site completely abolished the PknB $\mathrm{CD}_{-}-\mathrm{Gar} \mathrm{A}$ interaction (Table 2), in full agreement with previous observations that GarA was unable to interact with the dephosphorylated kinases PknB and PknG $(18,20)$. However, the same GarA substitution S95A had no effect on the KGD dissociation constant (Table 2 and fig. S8). This last result is consistent with a previous observation that this mutation did not affect KGD inhibition (13), but seems to contradict the essentiality of phosphomimetic KGD Asp ${ }^{795}$ (Figures 3C and 3E). This apparent discrepancy is probably due to a distinct pattern of interactions involving the Asp ${ }^{795}$ carboxylate (compared to a pThr residue) in the phosphatebinding pocket. The carboxylate group is hydrogen bonded to the hydroxyl group of $\mathrm{Ser}^{95}$ and to a water molecule, which in turn makes strong hydrogen bonds with $\mathrm{Asn}^{117}$ and main chain backbone atoms of GarA (Fig. 3C). Because it disrupts the whole H-bonding network, the substitution of KGD Asp ${ }^{795}$ is therefore expected to have a stronger effect on the binding energy than that of GarA Ser ${ }^{95}$.

In addition to the dissimilarities in the phosphate-binding pocket (occupation by pThr versus Asp), the PknB $\mathrm{BD}_{\mathrm{C}}-\mathrm{Gar} \mathrm{A}$ and KGD-GarA complexes also differ in the interactions on the positively charged face of the FHA domain: substitutions of the GarA basic residues R62A, K141E or R143A in the loops $\beta 1-\beta 2$ and $\beta 10-\beta 11$ had little or no effect on the $P k_{n} B_{C D}$ binding affinity (Table 2 and fig. S8). In contrast, these same substitutions were found to considerably affect KGD binding (Table 2), because the basic residues make several ionic interactions with the KGD loop 586-594 (Fig. 3D). In summary, the above observations suggest that recognition of KGD is driven by extensive interactions, not only with the phosphate-binding pocket but 
also with the adjacent basic cleft of GarA, which are required to efficiently block KGD protein motions during catalysis, whereas recognition of autophosphorylated PknB (or the GarA Nterminal phosphopeptide in the auto-inhibited closed form $(12,13))$ is dominated by interactions of the pThr residue with the canonical phosphate-binding pocket of GarA.

\section{DISCUSSION}

FHA domains are the only type of eukaryotic-like phosphoresidue-binding protein modules so far identified in bacteria, where they fulfill important albeit poorly characterized roles. For instance, in M. tuberculosis at least five FHA domain-containing proteins were reported to participate in the STPK-mediated control of essential biological processes such as cell wall synthesis $(14,41)$, cell division (42) and central metabolism (18). In particular, the GarAmediated control of a crucial node at the crossroads of carbon and nitrogen metabolism, conserved in and restricted to Actinobacteria (Fig. 1B), arguably represents the bacterial FHA domain-mediated signaling pathway with the most complete molecular description so far. Taken together with previous studies on mycobacterial GarA and corynebacterial $\operatorname{OdhI}(13,18$, 19, 22-25), our results substantially broaden the functional versatility of the FHA domain, beyond that of a simple pThr-recognition module in cell signaling. In particular, the structures of the upstream and downstream GarA complexes demonstrated how a single FHA domain protein can engage its canonical phosphate-binding pocket in biologically relevant, specific phosphorylation-dependent as well as phosphorylation-independent protein-protein interactions (Fig. 4). Moreover, the same binding region of the FHA domain is likely involved in the interaction of GarA with at least two other metabolic, structurally unrelated enzymes, because the amino acid substitutions S95A in the phosphate-binding pocket and K141E in the 
adjacent basic region were shown to abolish GarA binding and regulation of glutamate synthase and NAD-dependent glutamate dehydrogenase in mycobacteria (13).

This dual binding specificity of the FHA domain can be partially accounted for by phosphate mimicry of KGD Asp ${ }^{795}$, which is crucial for complex formation and occupies the phosphatebinding pocket. Indeed, aspartate and glutamate are frequently used as "phosphomimetic" residues to probe the constitutively phosphorylated state in protein phosphoregulation studies, even for structural studies $(43,44)$. Although in some cases it has been suggested that phosphomimetic mutations might enhance FHA binding (45-47), there have been no previous structural evidence for this and extensive literature rather suggested that phosphomimetic residues might not fit into the binding site of FHA domains or other adaptor proteins $((48)$ and references therein). Here, the structure of the KGD-GarA complex illustrates a clear example of functional phosphomimetics. The carboxylate group of KGD Asp ${ }^{795}$, a residue essential for complex formation with GarA, occupies a similar position as the pThr side chain in the PknBGarA complex, with a water molecule filling the cavity left by the missing oxygen atoms of the phosphate to partially restore the hydrogen bonding network (Fig. 3C). These observations demonstrate that phosphomimetic recognition by FHA domains is possible, although in this case we should emphasize that it is favored by additional protein-protein interactions outside the phosphate-binding pocket.

Besides contributing to a better understanding of the GarA-mediated signaling pathway at the molecular level, the individual crystal structures reported here raise important mechanistic issues. For instance, the role of protein dynamics in enzyme function remains poorly understood or difficult to interpret (49). The crystal structures of $\operatorname{KGD}(21,37)$ stressed the importance of protein motions for efficient catalysis and regulation, and that of the GarA-KGD complex now 
illustrates a potential approach for using dynamics to modulate function (50) and eventually to design efficient enzyme inhibitors. On the other hand, the structure of the PknB-GarA complex raises puzzling questions on the kinase activation mechanism. Phosphorylation of the activation loop is a hallmark of the active state for many Ser/Thr protein kinases $(32,51)$, because it usually leads to conformational changes required for catalysis (52). In PknB, phosphorylation of two Thr residues at the activation loop are also required for full kinase activity (53), but the structural and activity studies reported above suggest that the interaction between the pThr residues and the HRD motif is not required to achieve a catalytically competent active site. Instead it appears that phosphorylation of the activation loop serves to generate a docking site for FHA domain-mediated GarA recruitment, which accounts for the high kinase activity against this particular substrate. Further experiments are required to elucidate the molecular mechanisms underpinning kinase activation against other PknB substrates.

In summary, the work reported here revealed structural snapshots of a single FHA domain protein caught in upstream and downstream protein-protein complexes, providing important insights not only into the functional adaptability of these domains in bacterial signaling, but also into kinase activation and unanticipated allosteric dynamic mechanisms of metabolic regulation.

\section{MATERIALS AND METHODS}

\section{Reagents}

The synthetic 17-mer peptide SDEVTVETTSVFRADFL, corresponding to residues 14-30 of M. tuberculosis GarA (MtGarA) was purchased from Thermo Fisher Scientific (purity $>98 \%$ ). 


\section{Cloning and mutagenesis}

Genes were amplified by PCR from genomic DNA of Mycobacterium smegmatis mc ${ }^{2} 155$ (MSMEG_5049 for $k g d$, MSMEG_3647 for garA, MSMEG_4283 for dlaT and MSMEG_0903 for $l p d A$ ) and Mycobacterium tuberculosis H37Rv (Rv0014c for $p k n B$, Rv0243c for gabD1, Rv1827 for garA), and cloned into pET-28a (Novagen) or pDEST17 (Invitrogen) as previously described $(21,26,28)$. Site-directed mutagenesis was performed on pET28a-MtPknB $\mathrm{B}_{\mathrm{CD}}$ (L33E), pET28a-MsKGD ${ }_{\Delta 360}(\mathrm{R} 802 \mathrm{~A}, \mathrm{D} 795 \mathrm{~A}, \mathrm{~S} 484 \mathrm{R} / \mathrm{A} 488 \mathrm{Q})$ and pET28a-MsGarA (R62A, S95A, K141E, R143A). All plasmids were verified by DNA sequencing.

\section{Protein production}

The recombinant proteins $M s \mathrm{KGD}, M s \mathrm{KGD}_{\Delta 360}, M s \mathrm{GarA}, M s \mathrm{DlaT}, M s \mathrm{Lpd}, M t \mathrm{GabD} 1$, $M t \mathrm{GarA}$, and the two FHA domains alone $\left(M s \mathrm{GarA}_{\Delta 44}\right.$ used in co-crystallization with $\mathrm{KGD}_{\Delta 360}$ and $M t \mathrm{GarA}_{\Delta 43}$ used for the kinase assays shown in Fig. $2 \mathrm{~F}$ ) were over-produced in E. coli and purified as previously described $(21,26) . M s$ GarA and its mutant versions were also produced in microfermentor units, following established protocols (54). Mt $\mathrm{PknB}_{1-279}$ (referred to as $\left.\mathrm{PknB}_{\mathrm{CD}}\right)$ and its mutant version carrying the substitution L33E ( $\left.\mathrm{PknB}_{\mathrm{CD}, \mathrm{L} 33 \mathrm{E}}\right)$ were expressed for $15 \mathrm{~h}$ at $22^{\circ} \mathrm{C}$ with $100 \mu \mathrm{M}$ IPTG isopropyl-1-thio- $\beta$ D-galactopyranoside. Both proteins were purified using the same protocol. E. coli cells were harvested by centrifugation, re-suspended in lysis buffer $\left(50 \mathrm{mM} \mathrm{NaH}_{2} \mathrm{PO}_{4} \mathrm{pH} 8,500 \mathrm{mM} \mathrm{NaCl}, 5 \%\right.$ glycerol, $25 \mathrm{mM}$ imidazole, $1 \mathrm{mM}$ DTT) supplemented with Complete protease inhibitor cocktail (Roche) and sonicated. After centrifugation, the supernatant was loaded onto a $5 \mathrm{ml}$ HisTrap HP column (GE Healthcare) and the His-tagged protein was purified applying a linear imidazole gradient $(25-500 \mathrm{mM})$. Next, the His 6 tag was removed by incubating for 18 hours at $18{ }^{\circ} \mathrm{C}$ in the presence of His6tagged TEV protease (55) at a 1/30 ratio (w/w) in buffer $25 \mathrm{mM}$ Hepes $\mathrm{pH} 8,150 \mathrm{mM} \mathrm{NaCl}$, 
$5 \%$ glycerol, 1 mM DTT, followed by separation on a Ni-NTA agarose column (Qiagen). Then the protein was further purified by size-exclusion chromatography on a Superdex 200 column (GE Healthcare) equilibrated in $25 \mathrm{mM}$ Hepes $\mathrm{pH} 8,150 \mathrm{mM} \mathrm{NaCl}, 5 \%$ glycerol, $1 \mathrm{mM}$ DTT. Fractions corresponding to the PknB peaks, as confirmed by SDS-PAGE, were later pooled and concentrated up to $40 \mathrm{mg} / \mathrm{ml}$, flash-frozen in liquid nitrogen and stored at $-80^{\circ} \mathrm{C}$.

All proteins were quantified by using the molar absorption coefficient predicted from the aminoacid sequence by the ProtParam tool (http://web.expasy.org/protparam/).

\section{Enzyme activity assays}

Kinase activity assays were performed in 96-well plates. Each activity measurement was performed in a final volume of $20 \mu \mathrm{l}$, containing $50 \mathrm{mM}$ Tris- $\mathrm{HCl} \mathrm{pH} \mathrm{7.4,} 0.1 \% \mathrm{v} / \mathrm{v} 2$ mercaptoethanol, 0.01\% v/v Brij-35, 2 mM MnCl $2,100 \mu \mathrm{M}\left[\gamma^{32} \mathrm{P}\right] \mathrm{ATP}(5-50 \mathrm{cpm} / \mathrm{pmol})$, and $330 \mu \mathrm{M} 17-$ mer peptide or $25 \mu \mathrm{M} M t \mathrm{GarA}$ as substrate. In addition, the kinase assays shown in Fig. $2 \mathrm{~F}$ were done in the absence or presence of $92 \mu \mathrm{M} M t \mathrm{GarA}_{\Delta 43}$. The enzyme concentration in the assays was $0.2-5 \mu \mathrm{M}$ and 3-12 $\mathrm{nM}$ when using the 17-mer peptide or $M t \mathrm{GarA}$ as substrates, respectively. The kinase reactions were started by the addition of $4 \mu 1$ $\left[\gamma^{32} \mathrm{P}\right] \mathrm{ATP}-\mathrm{Mn}^{+2}$ and were performed at room temperature. The reactions were stopped by the addition of phosphoric acid and $4 \mu 1$ of each reaction were spotted on P81 phosphocellulose papers (Whatman) using the epMotion 5070 (Eppendorf) workstation. The papers were washed in $0.01 \%$ phosphoric acid, dried, then measured and analyzed using a PhosphorImager (FLA9000 Starion, Fujifilm). Each reaction was performed in duplicates $(<10 \%$ variation $)$ and each assay was performed at least twice ( $<20 \%$ variation). In all cases, specific activity values were derived from reactions performed employing three different enzyme concentrations within the indicated ranges $(<20 \%$ variation), verifying a linear dependence of activity with kinase concentration. The proportion of 17 -mer peptide or $M t \mathrm{GarA}$ consumed in the reactions was 
lower than $10 \%$ and $30 \%$, respectively. $M t$ GarA consumption was verified to be linear in time up to $50 \%$ its initial concentration. Under the experimental conditions employed to test phosphorylation of the 17-mer peptide or $M t \mathrm{GarA}, \mathrm{PknB}_{\mathrm{CD}}$ or $\mathrm{PknB} \mathrm{CD}_{\mathrm{C}, \mathrm{L} 33 \mathrm{E}}$ autophosphorylation represented less than $5 \%$ of the total signal. The measured signal was at least five times higher than the lecture on the background.

Determinations of 2-oxoglutarate decarboxylase and 2-oxoglutarate dehydrogenase (ODH) activities were carried out as previously described (21). Briefly, for the decarboxylase activity reactions contained $2 \mu \mathrm{M} M s \mathrm{KGD}_{\Delta 360}, 1-3 \mathrm{mM}$ 2-oxoglutarate, $0.2 \mathrm{mM}$ ThDP, $1 \mathrm{mM} \mathrm{MgCl} 2$, 0.55-1.1 $\mu \mathrm{M} M t \mathrm{GabD} 1,1-2 \mathrm{mM} \mathrm{NADP}{ }^{+}$in $50 \mathrm{mM}$ potassium phosphate, $\mathrm{pH}$ 6.5. Reactions were started by the addition of 2-oxoglutarate at $37^{\circ} \mathrm{C}$, and initial rates were calculated during the linear phase of the reaction (10-20 min) following $340 \mathrm{~nm}$ absorbance using a microplate reader. For measuring $\mathrm{ODH}$ activity, the reaction contained 1-3 $\mathrm{mM}$ 2-oxoglutarate, $1 \mathrm{mM}$ CoA-SH, $0.2 \mathrm{mM}$ ThDP, 1 mM MgCl $2,2 \mu \mathrm{M}$ MsKGD, $4 \mu \mathrm{M}$ MsDlaT, $0.5 \mu \mathrm{M}$ MsLpd, 1-2 mM 3-acetylpyridine dinucleotide $\left(\mathrm{AcNAD}^{+}\right)$in $50 \mathrm{mM}$ potassium phosphate $\mathrm{pH}$ 6.5. $\mathrm{AcNAD}^{+}$ was used instead of $\mathrm{NAD}^{+}$in order to prevent enzyme inhibition by NADH. Reactions were started by the addition of 2-oxoglutarate at $37^{\circ} \mathrm{C}$, and initial rates were calculated during the linear phase of the reaction (10-20 min). When required, MsGarA was diluted in PBS and added to a final concentration ranging from 0.02 to $10 \mu \mathrm{M}$, and AcCoA to a final concentration ranging from 0.01 to $4 \mathrm{mM}$. The rate of $\mathrm{AcNAD}^{+}$reduction was calculated by spectrophotometry based on the absorption coefficient of $\mathrm{AcNADH}, \mathrm{H}^{+}\left(\varepsilon_{340 \mathrm{~nm}}=6220 \mathrm{M}^{-1} \mathrm{~cm}^{-1}\right)$. When appropriate, MsGarA was diluted in PBS and added to the assay mixture at $5 \mu \mathrm{M}$, unless otherwise stated. Experiments were performed in triplicate.

\section{Isothermal titration calorimetry}


Mt GarA binding to $\mathrm{PknB}_{\mathrm{CD}}$ or $\mathrm{PknB} \mathrm{B}_{\mathrm{CD}, \mathrm{L} 33 \mathrm{E}}$ were assayed by using the high precision VP-ITC system (MicroCal Inc.) with the following parameters: the ITC cell $(1.4 \mathrm{ml})$ contained $10 \mu \mathrm{M}$ of $M t$ PknB, preincubated with $2 \mu \mathrm{M}$ ATP in $25 \mathrm{mM}$ Hepes pH 7.5, $150 \mathrm{mM} \mathrm{NaCl}, 1 \mathrm{mM}$ DTT and the syringe $(150 \mu \mathrm{l})$ contained $250 \mu \mathrm{M} M t$ GarA in the same buffer. Sample solutions were thoroughly degassed under vacuum and each titration was performed at $15{ }^{\circ} \mathrm{C}$ by injections of $10 \mu 1$ every 210 seconds using a 290 r.p.m. rotating syringe. Raw heat signal collected with a $16 \mathrm{~s}$ filter was corrected for the dilution heat and normalized to the concentration of ligand injected. Data were fit to a bimolecular model using the Origin software provided by the manufacturer. ITC experiments were performed at least twice to ensure reproducibility. A representative experiment is shown in fig. S3, from which the reported thermodynamic parameters have been calculated.

\section{Analytical ultracentrifugation}

Sedimentation coefficients were determined at $20^{\circ} \mathrm{C}$, using a Beckman Coulter XL-I centrifuge equipped with an AN60-Ti rotor equipped with Rayleigh interference detection. Samples were centrifuged for $17 \mathrm{~h}$ at $42000 \mathrm{rpm}$ and profiles were recorded every $5 \mathrm{~min}$. Sedimentation scans were analyzed by the continuous size distribution procedure c(S) with the program Sedfit 15.01 (56). All c(S) distributions were calculated with a fitted frictional ratio $\mathrm{f} / \mathrm{f0}$ and a maximum entropy regularization procedure with a confidence level of 0.68 . Theoretical sedimentation coefficients were calculated from the atomic coordinates using HYDROPRO (57), and compared to the experimental sedimentation coefficients obtained from ultracentrifugation analysis.

\section{Surface plasmon resonance}


SPR measurements were performed at $25{ }^{\circ} \mathrm{C}$ on an NTA sensor chip using a Biacore 2000 instrument (GE Healthcare) equilibrated with $25 \mathrm{mM}$ Hepes pH 8, $150 \mathrm{mM} \mathrm{NaCl}, 50 \mu \mathrm{M}$ EDTA and $0.005 \%$ Tween 20 (running buffer). The sensor chip was activated by injecting $0.5 \mathrm{mM}$ $\mathrm{NiCl}_{2}$ followed by the capture of the His-tagged proteins $M s K G D$ full length and $M t P k n B C D$ on two independent channels. The reference flow cell was prepared by the same procedure in absence of protein. Various concentrations of wild-type $M s \mathrm{GarA}$, or the single point mutants R61A, S94A, K140E and R142A (referred to in the text as R62A, S95A, K141E and R143A, respectively, to maintain consistency with $M t$ GarA residue numbering) were injected onto the surfaces at a flow rate of $50 \mu 1 . \mathrm{min}^{-1}$ and the binding signals monitored. Protein dissociation was realized by injecting the running buffer and the surface was regenerated by injecting imidazole $0.25 \mathrm{M}$, followed by EDTA $0.35 \mathrm{M}$ and SDS $0.1 \%$ before the next cycle. Control flow cell sensorgrams were subtracted from the ligand flow cell sensorgrams and averaged buffer injections were subtracted from analyte sensorgrams. Response at equilibrium (Req) were obtained directly from the plateau region of the sensorgrams. The saturation curves obtained by plotting Req versus the analyte concentration were fitted with a steady state model to obtain the apparent equilibrium dissociation constant $\mathrm{K}_{\mathrm{D}}$, using the BIAevaluation 4.2 software (GE Healthcare).

\section{Crystallization and data collection}

Crystallization screenings were carried out using the sitting-drop vapor diffusion method and a Mosquito nanolitre-dispensing crystallization robot (TTP Labtech); hits were improved by hand-made hanging drops in 24-well plates at the same temperature. Optimized conditions for crystal growth of the different protein complexes (protein concentrations of $20-25 \mathrm{mg} / \mathrm{ml}$, molar ratios of 1:1) are as follows: (i) $M t \mathrm{PknB}_{\mathrm{L} 33 \mathrm{E}}-M t \mathrm{GarA}, 100 \mathrm{mM}$ Hepes, $4 \% \mathrm{w} / \mathrm{v}$ PEG400, $2 \mathrm{M}$ $\left(\mathrm{NH}_{4}\right)_{2} \mathrm{SO}_{4}, 4$ mM AMP-PCP, pH 7.5; (ii) $M s \mathrm{KGD}_{\Delta 360}-M_{s} \mathrm{GarA}_{\triangle 44}: 50 \% \mathrm{MPD}, 100 \mathrm{mM}$ MES, 
$2 \mathrm{mM}$ ThDP, $5 \mathrm{mM} \mathrm{MgCl}$, $\mathrm{pH}$ 6.5; and (iii) $M_{s} \mathrm{KGD}_{\Delta 360, \mathrm{R} 802 \mathrm{~A}}-M_{s} \mathrm{GarA}_{\Delta 44}: 47 \% \mathrm{MPD}, 100$ $\mathrm{mM}$ NaHepes, $2 \mathrm{mM}$ ThDP, $5 \mathrm{mM} \mathrm{MgCl}$, $\mathrm{pH}$ 7.5. The enamine-ThDP reaction intermediate for KGD in the presence of GarA was obtained by soaking crystals of the $M s K_{G D} D_{\triangle 360, R 802 A}$ $\mathrm{MsGarA}_{\Delta 44}$ (grown as described above) with $20 \mathrm{mM}$ 2-oxoglutarate for 8 minutes prior to freezing.

X-ray diffraction data were collected from single crystals at $100 \mathrm{~K}$ using synchrotron radiation at beamlines Proxima 1, Synchrotron Soleil (Saint-Aubin, France) and at ID14-1, ESRF (Grenoble, France). Data processing was carried out with programs XDS (58) and AIMLESS $(59)$.

\section{Structure determination and refinement}

The crystal structures of all protein complexes were solved by molecular replacement techniques using either the MtPknB catalytic domain (PDB code 1O6Y) or the apo form of $M s K \mathrm{D}_{\triangle 360}$ (PDB code 2YIC) as search probes with the program PHASER (60). The bound FHA domain in all structures, as well as the cofactor ThDP (for the KGD complexes) or the nucleotide AMP-PCP (for the PknB complex), were clearly visible in Fourier difference maps and could be manually traced during refinement. All crystallographic models were refined through iterative cycles of manual model building with COOT (61) and reciprocal space refinement with BUSTER (62). Due to important conformational changes in the PknB kinase core, the entire N-lobe was removed during the first refinement rounds and gradually rebuilt through iterative cycles of refinement and manual model building. The structure was validated through the Molprobity server (http://molprobity.biochem.duke.edu). Figures were generated and rendered with Pymol 1.5.0.2. (Schrödinger, LLC). 


\section{Supplementary Materials}

Fig. S1. Conserved amino acid sequences of GarA homologues in selected Actinobacteria.

Fig. S2. Continuous sedimentation coefficient distribution analysis of the $\mathrm{PknB}_{\mathrm{CD}}-\mathrm{Gar} \mathrm{A}$ complex.

Fig. S3. Isothermal titration calorimetry (ITC) characterization of the interaction between autophosphorylated $\mathrm{PknB}_{\mathrm{CD}}$ and GarA.

Fig. S4. The N-terminal GarA extension occupies a similar position in different GarA structures.

Fig. S5. Conserved mode of phosphopeptide recognition in different $M$. tuberculosis FHA domains.

Fig. S6. Detailed structure of the PknB activation loop bound to GarA.

Fig. S7. Formation of the enamine-ThDP covalent adduct in the presence of GarA.

Fig. S8. Surface plasmon resonance (SPR) studies of protein-protein interactions. 


\section{REFERENCES AND NOTES}

1. A. Wehenkel, M. Bellinzoni, M. Graña, R. Duran, A. Villarino, P. Fernandez, G. André-Leroux, P. England, H. Takiff, C. Cerveñansky, S. T. Cole, P. M. Alzari, Mycobacterial Ser/Thr protein kinases and phosphatases: physiological roles and therapeutic potential. Biochim. Biophys. Acta. 1784, 193-202 (2008).

2. S. F. F. Pereira, L. Goss, J. Dworkin, Eukaryote-Like Serine/Threonine Kinases and Phosphatases in Bacteria. Microbiol. Mol. Biol. Rev. 75, 192-212 (2011).

3. A. Kobir, L. Shi, A. Boskovic, C. Grangeasse, D. Franjevic, I. Mijakovic, Protein phosphorylation in bacterial signal transduction. Biochim. Biophys. Acta. 1810, 989994 (2011).

4. B. T. Seet, I. Dikic, M.-M. Zhou, T. Pawson, Reading protein modifications with interaction domains. Nat. Rev. Mol. Cell Biol. 7, 473-483 (2006).

5. J. Jin, T. Pawson, Modular evolution of phosphorylation-based signalling systems. Phil. Trans. Royal Soc. B: Biol. Sci . 367, 2540-2555 (2012).

6. I. Sadowski, J. C. Stone, T. Pawson, A noncatalytic domain conserved among cytoplasmic protein-tyrosine kinases modifies the kinase function and transforming activity of Fujinami sarcoma virus P130gag-fps. Mol. Cell. Biol. 6, 4396-4408 (1986).

7. M. Pallen, R. Chaudhuri, A. Khan, Bacterial FHA domains: neglected players in the phospho-threonine signalling game? Trends Microbiol. 10, 556-563 (2002).

8. K. Hofmann, P. Bucher, The FHA domain: a putative nuclear signalling domain found in protein kinases and transcription factors. Trends Biochem. Sci. 20, 347-349 (1995). 
9. A. Mahajan, C. Yuan, H. Lee, E. S. W. Chen, P.-Y. Wu, M.-D. Tsai, Structure and function of the phosphothreonine-specific FHA domain. Sci. Signal. 1, re12 (2008).

10. J. Li, G. P. Smith, J. C. Walker, Kinase interaction domain of kinase-associated protein phosphatase, a phosphoprotein-binding domain. Proc. Natl. Acad. Sci. U.S.A. 96, 7821-7826 (1999).

11. D. Durocher, S. P. Jackson, The FHA domain. FEBS Lett. 513, 58-66 (2002).

12. P. Barthe, C. Roumestand, M. J. Canova, L. Kremer, C. Hurard, V. Molle, M. CohenGonsaud, Dynamic and structural characterization of a bacterial FHA protein reveals a new autoinhibition mechanism. Structure 17, 568-578 (2009).

13. T. J. Nott, G. Kelly, L. Stach, J. Li, S. Westcott, D. Patel, D. M. Hunt, S. Howell, R. S. Buxton, H. M. O'Hare, S. J. Smerdon, An intramolecular switch regulates phosphoindependent FHA domain interactions in Mycobacterium tuberculosis. Sci. Signal. 2, ra12 (2009).

14. C. L. Gee, K. G. Papavinasasundaram, S. R. Blair, C. E. Baer, A. M. Falick, D. S. King, J. E. Griffin, H. Venghatakrishnan, A. Zukauskas, J.-R. Wei, R. K. Dhiman, D. C. Crick, E. J. Rubin, C. M. Sassetti, T. Alber, A phosphorylated pseudokinase complex controls cell wall synthesis in Mycobacteria. Sci. Signal. 5, ra7 (2012).

15. Y. Tong, W. Tempel, H. Wang, K. Yamada, L. Shen, G. A. Senisterra, F. MacKenzie, A. H. Chishti, H.-W. Park, Phosphorylation-independent dual-site binding of the FHA domain of KIF13 mediates phosphoinositide transport via centaurin alpha1. Proc. Natl. Acad. Sci. U.S.A. 107, 20346-20351 (2010).

16. A. W. Almawi, L. A. Matthews, Larasati, P. Myrox, S. Boulton, C. Lai, T. Moraes, G. 
Melacini, R. Ghirlando, B. P. Duncker, A. Guarné, 'AND' logic gates at work: Crystal structure of Rad53 bound to Dbf4 and Cdc7. Sci. Rep. 6, 34237 (2016).

17. M. Bott, Offering surprises: TCA cycle regulation in Corynebacterium glutamicum. Trends Microbiol. 15, 417-425 (2007).

18. H. M. O'Hare, R. Durán, C. Cerveñansky, M. Bellinzoni, A. M. Wehenkel, O. Pritsch, G. Obal, J. Baumgartner, J. Vialaret, K. Johnsson, P. M. Alzari, Regulation of glutamate metabolism by protein kinases in mycobacteria. Mol. Microbiol. 70, 1408$1423(2008)$.

19. A. E. Belanger, G. F. Hatfull, Exponential-phase glycogen recycling is essential for growth of Mycobacterium smegmatis. J. Bacteriol. 181, 6670-6678 (1999).

20. A. Villarino, R. Duran, A. Wehenkel, P. Fernandez, P. England, P. Brodin, S. T. Cole, U. Zimny-Arndt, P. R. Jungblut, C. Cerveñansky, P. M. Alzari, Proteomic identification of M. tuberculosis protein kinase substrates: PknB recruits GarA, a FHA domain-containing protein, through activation loop-mediated interactions. J. Mol. Biol. 350, 953-963 (2005).

21. T. Wagner, M. Bellinzoni, A. Wehenkel, H. M. O'Hare, P. M. Alzari, Functional plasticity and allosteric regulation of $\alpha$-ketoglutarate decarboxylase in central mycobacterial metabolism. Chem. Biol. 18, 1011-1020 (2011).

22. B. Rieck, G. Degiacomi, M. Zimmermann, A. Cascioferro, F. Boldrin, N. R. LazarAdler, A. R. Bottrill, F. le Chevalier, W. Frigui, M. Bellinzoni, M. N. Lisa, P. M. Alzari, L. Nguyen, R. Brosch, U. Sauer, R. Manganelli, H. M. O'Hare, PknG senses amino acid availability to control metabolism and virulence of Mycobacterium tuberculosis. PLoS Pathog. 13, e1006399 (2017). 
23. A. Niebisch, A. Kabus, C. Schultz, B. Weil, M. Bott, Corynebacterial protein kinase G controls 2-oxoglutarate dehydrogenase activity via the phosphorylation status of the OdhI protein. J. Biol. Chem. 281, 12300-12307 (2006).

24. C. Schultz, A. Niebisch, L. Gebel, M. Bott, Glutamate production by Corynebacterium glutamicum: dependence on the oxoglutarate dehydrogenase inhibitor protein OdhI and protein kinase PknG. Appl. Microbiol. Biotechnol. 76, 691-700 (2007).

25. M. Ventura, B. Rieck, F. Boldrin, G. Degiacomi, M. Bellinzoni, N. Barilone, F. Alzaidi, P. M. Alzari, R. Manganelli, H. M. O'Hare, GarA is an essential regulator of metabolism in Mycobacterium tuberculosis. Mol. Microbiol. 90, 356-366 (2013).

26. P. England, A. Wehenkel, S. Martins, S. Hoos, G. André-Leroux, A. Villarino, P. M. Alzari, The FHA-containing protein GarA acts as a phosphorylation-dependent molecular switch in mycobacterial signaling. FEBS Lett. 583, 301-307 (2009).

27. T. Alber, Signaling mechanisms of the Mycobacterium tuberculosis receptor Ser/Thr protein kinases. Curr. Op. Struct. Biol. 19, 650-657 (2009).

28. M. Ortiz-Lombardía, F. Pompeo, B. Boitel, P. M. Alzari, Crystal structure of the catalytic domain of the PknB serine/threonine kinase from Mycobacterium tuberculosis. J. Biol. Chem. 278, 13094-13100 (2003).

29. T. A. Young, B. Delagoutte, J. A. Endrizzi, A. M. Falick, T. Alber, Structure of Mycobacterium tuberculosis $\mathrm{PknB}$ supports a universal activation mechanism for Ser/Thr protein kinases. Nat. Struct. Biol. 10, 168-174 (2003).

30. T. N. Lombana, N. Echols, M. C. Good, N. D. Thomsen, H.-L. Ng, A. E. Greenstein, A. M. Falick, D. S. King, T. Alber, Allosteric activation mechanism of the 
Mycobacterium tuberculosis receptor Ser/Thr protein kinase, PknB. Structure 18, 1667-1677 (2010).

31. A. Wehenkel, P. Fernandez, M. Bellinzoni, V. Catherinot, N. Barilone, G. Labesse, M. Jackson, P. M. Alzari, The structure of PknB in complex with mitoxantrone, an ATPcompetitive inhibitor, suggests a mode of protein kinase regulation in mycobacteria. FEBS Lett. 580, 3018-3022 (2006).

32. M. Huse, J. Kuriyan, The conformational plasticity of protein kinases. Cell 109, 275$282(2002)$

33. Y. Usuda, N. Tujimoto, C. Abe, Y. Asakura, E. Kimura, Y. Kawahara, O. Kurahashi, H. Matsui, Molecular cloning of the Corynebacterium glutamicum (“ Brevibacterium lactofermenturn" AJ12036) odhA gene encoding a novel type of 2-oxoglutarate dehydrogenase. Microbiology 142, 3347-3354 (1996).

34. J. Tian, R. Bryk, M. Itoh, M. Suematsu, C. Nathan, Variant tricarboxylic acid cycle in Mycobacterium tuberculosis: identification of alpha-ketoglutarate decarboxylase. Proc. Natl. Acad. Sci. U.S.A. 102, 10670-10675 (2005).

35. T. Saito, S. Tuboi, Y. Nishimura, G. Kikuchi, On the nature of the enzyme which catalyzes a synergistic decarboxylation of alpha-ketoglutarate and glyoxylate. $J$. Biochem. 69, 265-273 (1971).

36. L. P. S. de Carvalho, H. Zhao, C. E. Dickinson, N. M. Arango, C. D. Lima, S. M. Fischer, O. Ouerfelli, C. Nathan, K. Y. Rhee, Activity-based metabolomic profiling of enzymatic function: Identification of Rv1248c as a mycobacterial 2-hydroxy-3oxoadipate synthase. Chem. Biol. 17, 323-332 (2010). 
37. T. Wagner, N. Barilone, P. M. Alzari, M. Bellinzoni, A dual conformation of the postdecarboxylation intermediate is associated with distinct enzyme states in mycobacterial KGD ( $\alpha$-ketoglutarate decarboxylase). Biochem. J. 457, 425-434 (2014).

38. K. Raasch, M. Bocola, J. Labahn, A. Leitner, L. Eggeling, M. Bott, Interaction of 2oxoglutarate dehydrogenase OdhA with its inhibitor OdhI in Corynebacterium glutamicum: Mutants and a model. J. Biotechnol. 191, 99-105 (2014).

39. A. Balakrishnan, F. Jordan, C. F. Nathan, Influence of allosteric regulators on individual steps in the reaction catalyzed by Mycobacterium tuberculosis 2-hydroxy-3oxoadipate synthase. J. Biol. Chem. 288, 21688-21702 (2013).

40. T. Wagner, Structural insights into mycobacterial central carbon metabolism: the catalytic mechanisms and regulatory properties of alpha-ketoglutarate decarboxylase (KGD). PhD thesis, University Pierre and Marie Curie, Paris, France (2011).

41. K. Sharma, M. Gupta, M. Pathak, N. Gupta, A. Koul, S. Sarangi, R. Baweja, Y. Singh, Transcriptional control of the mycobacterial embCAB operon by $\mathrm{PknH}$ through a regulatory protein, EmbR, in vivo. J. Bacteriol. 188, 2936-2944 (2006).

42. K. J. Kieser, E. J. Rubin, How sisters grow apart: mycobacterial growth and division. Nat Rev. Microbiol. 12, 550-562 (2014).

43. P. D. Mace, Y. Wallez, M. F. Egger, M. K, Dobaczewska, H. Robinson, E. B. Pasquale, S. J. Ried1, Structure of ERK2 bound to PEA-15 reveals a mechanism for rapid release of activated MAPK. Nat. Commun. 4, 37 (2013).

44. J. Oberoi, D. M. Dunn, M. R. Woodford, L. Mariotti, J. Schulman, D. Bourboulia, M. Mollapour, C. K Vaughan, Structural and functional basis of protein phosphatase 5 
substrate specificity. Proc. Natl. Acad. Sci. U.S.A. 113, 9009-9014 (2016).

45. K. Matsuzaki, A. Shinohara, M. Shinohara, Forkhead-Associated domain of yeast Xrs2, a homolog of human Nbs1, promotes nonhomologous end joining through interaction with a ligase IV partner protein, Lif1. Genetics 179, 213-225 (2008).

46. Z. Cai, N. H. Chehab, N. P. Pavletich, Structure and activation mechanismof the CHK2 DNA damage checkpoint kinase. Mol. Cell 35, 818-829 (2009).

47. Y.-S. Huoh, K. M. Ferguson, The pellino E3 ubiquitin ligases recognize specific phosphothreonine motifs and have distinct substrate specificities. Biochemistry 53, 4946-4955 (2014).

48. N. Dephoure, K. L. Gould, S. P. Gygi, D. R. Kellogg, Mapping and analysis of phosphorylation sites: a quick guide for cell biologists. Mol. Biol. Cell. 24, 535-542 (2013).

49. C. Narayanan, D. Bernard, N. Doucet, Role of conformational motions in enzyme function: Selected methodologies and case studies. Catalysts 6, 81 (2016).

50. R. J. Swett, G. A. Cisneros, A. L. Feig, Disruption of intrinsic motions as a mechanism for enzyme inhibition. Biophys. J. 105, 494-501 (2013).

51. C. A. Dodson, T. Haq, S. Yeoh, A. M. Fry, R. Bayliss, The structural mechanisms that underpin mitotic kinase activation. Biochem. Soc. Trans. 41, 1037-1041 (2013).

52. L. R. Pearce, D. Komander, D. R. Alessi, The nuts and bolts of AGC protein kinases. Nat. Rev. Mol. Cell. Biol. 11, 9-22 (2010).

53. B. Boitel, M. Ortiz-Lombardia, R. Durán, F. Pompeo, S. T. Cole, C. Cerveñansky, P. 
M. Alzari, PknB kinase activity is regulated by phosphorylation in two Thr residues and dephosphorylation by PstP, the cognate phospho-Ser/Thr phosphatase, in Mycobacterium tuberculosis. Mol. Microbiol. 49, 1493-1508 (2003).

54. E. Frachon, V. Bondet, H. Munier-Lehmann, J. Bellalou, Multiple microfermentor battery: a versatile tool for use with automated parallel cultures of microorganisms producing recombinant proteins and for optimization of cultivation protocols. Appl. Environ. Microbiol. 72, 5225-5231 (2006).

55. S. van den Berg, P.-A. Löfdahl, T. Härd, H. Berglund, Improved solubility of TEV protease by directed evolution. J. Biotechnol. 121, 291-298 (2006).

56. P. Schuck, Size-distribution analysis of macromolecules by sedimentation velocity ultracentrifugation and Lamm equation modeling. Biophys. J. 78, 1606-1619 (2000).

57. A. Ortega, D. Amoros, J. Garcia de la Torre, Prediction of hydrodynamic and other solution properties of rigid proteins from atomic- and residue-level models. Biophys. J. 101, 892-898 (2011).

58. W. Kabsch, XDS. Acta Cryst. D66, 125-132 (2010).

59. P. R. Evans, G. N. Murshudov, How good are my data and what is the resolution? Acta Cryst. D69, 1204-1214 (2013).

60. A. J. McCoy, R. W. Grosse-Kunstleve, P. D. Adams, M. D. Winn, L. C. Storoni, R. J. Read, Phaser crystallographic software. J. Appl. Cryst. 40, 658-674 (2007).

61. P. Emsley, K. Cowtan, Coot: model-building tools for molecular graphics. Acta Cryst. D60, 2126-2132 (2004). 
62. G. Bricogne, E. Blanc, M. Brandl, C. Flensburg, P. Keller, P. Paciorek, P. Roversi, A. Sharff, O. Smart, C. Vonrhein, T. Womack. BUSTER version 2.10.3. Cambridge, United Kingdom: Global Phasing Ltd. (2017).

63. K.-A. Boulahya, E. Guedon, S. Delaunay, C. Schultz, J. Boudrant, M. Bott, J.-L. Goergen, OdhI dephosphorylation kinetics during different glutamate production processes involving Corynebacterium glutamicum. Appl. Microbiol. Biotechnol. 87, $1867-1874$ (2010).

64. S. Pennell, S. Westcott, M. Ortiz-Lombardia, D. Patel, J. Li, T. J. Nott, D. Mohammed, R. S. Buxton, M. B. Yaffe, C. Verma, S. J. Smerdon, Structural and functional analysis of phosphothreonine-pependent FHA domain interactions. Structure 18, 1587-1595 (2010).

65. L. J. Alderwick, V. Molle, L. Kremer, A. J. Cozzone, T. R. Dafforn, G. S. Besra, K. Fütterer, Molecular structure of EmbR, a response element of Ser/Thr kinase signaling in Mycobacterium tuberculosis. Proc. Natl. Acad. Sci. U.S.A. 103, 2558-2563 (2006). 
Acknowledgements: We thank Ricardo Biondi for assistance with kinase assays and helpful discussions, Ahmed Haouz and Patrick Weber (Crystallography Platform, Institut Pasteur) for their help with robot-driven crystallization screenings, Jacques Bellalou (Recombinant Proteins Platform, Institut Pasteur) for help in protein production, and Francis Schaeffer (Structural Microbiology Unit, Institut Pasteur) for assistance with ITC measurements. We acknowledge the synchrotron sources Soleil (Saint-Aubin, France) and ESRF (Grenoble, France) for granting access to their facilities, and their staff members for helpful assistance. Funding: This work was partially supported by grants from the Institut Pasteur and the CNRS. MNL received postdoctoral fellowships from EMBO (European Molecular Biology Organization) and FRM (Fondation pour la Recherche Medicale, France). Authors contributions: M.B. and P.M.A. designed the experiments; T.W., G.A.L., V.H., M.N.L., N.B., and B.V.L.N. performed the experiments; T.W., G.A.L., M.N.L., S.H., B.R., H.O., M.B. and P.M.A. analyzed the data; T.W., G.A.L., M.N.L., O.H., M.B. and P.M.A. wrote the manuscript. Competing interests: The authors declare that they have no competing interests. Data and materials availability: The atomic coordinates and structure factors of the four crystal structures were deposited in the Protein Data Bank with codes 6I2P $\left(M t \mathrm{PknB}_{\mathrm{CD}, \mathrm{L} 33 \mathrm{~A}}-M t \mathrm{GarA}\right)$, 6I2Q $\left(M s \mathrm{KGD}_{\Delta 360}-M s \mathrm{GarA}_{\Delta 44}\right)$,

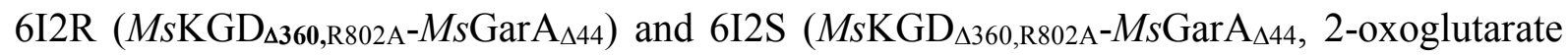
soak). All other data needed to evaluate the conclusions in the paper are present in the paper or the Supplementary Materials. 


\section{FIGURE LEGENDS}

Fig. 1. GarA regulates glutamate metabolism in actinobacteria. (A) GarA consists of a Cterminal FHA domain and an N-terminal peptide extension that contains two adjacent phosphorylatable threonine residues: $\operatorname{Thr}^{21}$ and $\operatorname{Thr}^{22}$ in M. tuberculosis $\operatorname{Gar} \mathrm{A}(18,20)$ (equivalent to $\mathrm{Thr}^{14}$ and $\mathrm{Thr}^{15}$ in the C. glutamicum homologue OdhI (17)). PknG phosphorylates the first Thr in each protein, whereas PknB targets the second Thr residue in each protein. (B) The mycobacterial signaling pathway involving GarA, which functions as a phospho-dependent (ON/OFF) molecular switch (26). In the ON state, nonphosphorylated GarA represses or stimulates the activity of three distinct metabolic enzymes and redirects the metabolic flux (thick grey lines) towards the synthesis of glutamate. GarA binding to its downstream targets involves pThr-independent recognition by the GarA FHA domain, which is rare among FHA domains. Phosphorylation of GarA by PknG or PknB triggers an intramolecular interaction, resulting in a closed conformation that blocks the pThr-binding site and switches off the regulatory properties of GarA. Dephosphorylation of GarA by PstP, the conserved transmembrane protein serine-threonine phosphatase in Actinobacteria, is assumed based on PstP-mediated dephosphorylation of OdhI in C. glutamicum (63). ODH, 2oxoglutarate dehydrogenase; GS, glutamate synthase; GDH, glutamate dehydrogenase; OG, 2oxoglutarate; Glu, glutamate; Gln, glutamine; SucCoA, succinyl-Coenzyme A. 
Fig. 2. Structure of the upstream ternary complex GarA-PknB-nucleotide. (A) Overall view of the GarA-PknB ${ }_{\text {CD,L33E }}$ complex. The complex was crystallized in the presence of the non-hydrolysable ATP analog AMP-PCP. GarA is shown in yellow, the PknB kinase activation loop in violet, and the two $\mathrm{PknB}$ helices involved in the interface in green. The nonhydrolysable ATP analog and the residues involved in Thr-phosphate binding are depicted as sticks. (B) The N-terminal GarA peptide (residues 26-34) mediates the interaction between a patch of basic residues on the FHA domain surface $\left(\operatorname{Arg}^{62}, \operatorname{Arg}^{143}\right)$ and the PknB helix $\alpha \mathrm{G}$. (C) Close view of the $\mathrm{pThr}^{171}$-binding site, with all phosphate oxygens involved in H-bonding interactions. (D) Structural differences in the PknB helix $\alpha \mathrm{C}$ between the PknB-GarA complex (green) and the back-to-back PknB homodimer (blue, PDB code 1O6Y). (E) Kinase activity of $\mathrm{PknB}_{\mathrm{CD}}$ and $\mathrm{PknB} \mathrm{CD}_{\mathrm{C}, \mathrm{L} 3 \mathrm{~A}}$ on full-length GarA (orange) and on the 17-residue peptide substrate (green). (F) Kinase activity of $\mathrm{PknB}_{\mathrm{CD}}$ and $\mathrm{PknB}_{\mathrm{CD}, \mathrm{L} 33 \mathrm{~A}}$ on the peptide substrate in the absence (light green) and presence (dark green) of the GarA FHA domain. In panels E and F, values are the mean of three independent measurements $(\mathrm{N}=3)$ and error bars represent the SEM. 
Fig. 3. The downstream GarA FHA domain $\left(\operatorname{GarA}_{\Delta 44)-E 10}\left(\operatorname{KGD}_{\Delta 360}\right)\right.$ complex. (A) Two GarA FHA domain molecules (yellow) bind the outer helices (475-500) and (785-813) of the E1o homodimer (pink). The cofactor thiamine diphosphate (ThDP) at the E1o active site is shown in sphere representation. (B) Overall view of the protein-protein interface, showing the molecular surface of KGD color-coded according to electrostatic charge, and GarA FHA domain in ribbon representation. The electrostatic surface is represented color-coded from acidic (red) to basic (blue). All protein residues involved in intermolecular $\mathrm{H}$ bonds are labelled (black label for GarA residues, white labels for surface KGD residues). (C) Close view of the pThr-binding pocket showing atomic interactions of the phospho-mimetic residue Asp $^{795}$. Color-code as in panel (A). (D) Hydrogen bonds between GarA FHA domain Arg ${ }^{62}$ and $\mathrm{Arg}^{143}$ (in yellow) and main chain carbonyl groups from the KGD loop 586-594 (in violet, side chains are omitted for clarity). (E) GarA FHA domain inhibition of wild-type $\mathrm{KGD}_{\triangle 360}$ (red) and three interface mutants (D759A: black open circles, S484A/A488R: black dots, R802A: green). Values are the mean of three independent measurements ( $N=3)$; SEM values (not shown) are in the range 0.1-0.5. 
Fig. 4. The GarA FHA domain employs the same binding region (colored molecular surface) in distinct functional contexts. The structures shown are those of the closed conformation of autoinhibited GarA (left panel), the GarA-PknB ${ }_{\mathrm{CD}, \mathrm{L} 33 \mathrm{~A}}$ complex (central panel) and the

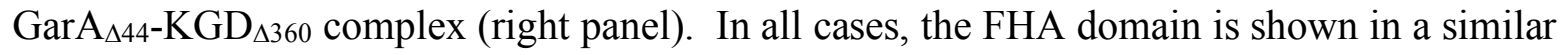
orientation. 
Table 1. Data collection and refinement statistics

\begin{tabular}{|c|c|c|c|c|}
\hline Data collection & PknB ${ }_{C D}-$ GarA & $\begin{array}{l}\text { KGD }_{\Delta 360-} \\
\operatorname{Gar} A_{\Delta 44}\end{array}$ & $\begin{array}{c}\text { KGD }_{\Delta 360, R_{02 A^{-}}} \\
\operatorname{Gar}_{\Delta 44}\end{array}$ & $\begin{array}{c}\text { KGD }_{\Delta 360, \mathrm{R}_{02} \mathrm{~A}^{-}} \\
\text {Gar }_{\Delta 44} \\
\text { 2-oxoglutarate soak }\end{array}$ \\
\hline $\begin{array}{l}\text { Synchrotron } \\
\text { beamline }\end{array}$ & $\begin{array}{c}\text { SOLEIL Proxima } \\
1 \\
\end{array}$ & $\begin{array}{c}\text { SOLEIL Proxima } \\
1\end{array}$ & ESRF ID14-1 & SOLEIL Proxima 1 \\
\hline Wavelength $(\AA)$ & 0.9763 & 0.9800 & 0.9334 & 0.9801 \\
\hline Space group & $\mathrm{P} 2{ }_{1} 2_{1} 2_{1}$ & C2 221 & $\mathrm{P} 2{ }_{1} 2_{1} 2_{1}$ & C2 221 \\
\hline $\begin{array}{l}\text { Cell dimensions } \\
a, b, c(\AA)\end{array}$ & $\begin{array}{c}\text { 69.31, 70.46, } \\
188.60\end{array}$ & $\begin{array}{c}141.25,167.85 \\
102.81\end{array}$ & $\begin{array}{c}95.75,143.15 \\
167.11\end{array}$ & $\begin{array}{c}141.27,168.06 \\
101.57\end{array}$ \\
\hline$\alpha, \beta, \gamma\left({ }^{\circ}\right)$ & $90,90,90$ & $90,90,90$ & $90,90,90$ & $90,90,90$ \\
\hline Resolution $(\AA)$ & $\begin{array}{l}38.85-2.37 \\
(2.46-2.37)\end{array}$ & $\begin{array}{l}47.83-2.15 \\
(2.20-2.15)\end{array}$ & $\begin{array}{l}48.15-2.20 \\
(2.24-2.20)\end{array}$ & $\begin{array}{l}84.03-2.40 \\
(2.45-2.40)\end{array}$ \\
\hline$R_{\text {merge }}$ & $0.081(0.439)$ & $0.062(0.747)$ & $0.089(0.746)$ & $0.075(0.840)$ \\
\hline$I / \sigma(I)$ & $10.5(2.4)$ & $16.6(2.2)$ & $13.2(1.6)$ & $13.9(2.2)$ \\
\hline Completeness (\%) & $96.3(78.9)$ & $98.9(98.4)$ & $96.7(69.1)$ & $98.0(100.0)$ \\
\hline $\mathrm{CC}(1 / 2)$ & $0.995(0.863)$ & $0.999(0.760)$ & $0.997(0.716)$ & $0.992(0.810)$ \\
\hline Redundancy & $4.6(4.0)$ & $5.0(5.1)$ & $5.9(2.6)$ & $4.7(5.0)$ \\
\hline \multicolumn{5}{|l|}{ Refinement } \\
\hline Resolution $(\AA)$ & 2.37 & 2.15 & 2.20 & 2.40 \\
\hline No. reflections & 36656 & 65660 & 112917 & 46357 \\
\hline$R_{\text {work } /} R_{\text {free }}(\%)$ & $22.0 / 23.4$ & $16.3 / 19.1$ & $19.5 / 21.9$ & $19.2 / 21.9$ \\
\hline \multicolumn{5}{|l|}{ No. atoms } \\
\hline Protein & 5631 & 7167 & 14168 & 7094 \\
\hline Ligand/ions & 148 & 28 & 56 & 40 \\
\hline Solvent & 228 & 356 & 454 & 159 \\
\hline \multicolumn{5}{|l|}{ Average B-factors } \\
\hline Protein & 67.8 & 56.7 & 35.4 & 72.8 \\
\hline Ligand/ions & 65.4 & 34.0 & 22.8 & 62.8 \\
\hline Solvent & 60.7 & 49.0 & 29.7 & 58.2 \\
\hline \multicolumn{5}{|l|}{ R.m.s deviations } \\
\hline Bond lengths $(\AA)$ & 0.008 & 0.010 & 0.010 & 0.010 \\
\hline Bond angles $\left({ }^{\circ}\right)$ & 0.99 & 0.99 & 1.01 & 1.08 \\
\hline PDB \# & $612 P$ & $612 Q$ & 6I2R & $612 S$ \\
\hline
\end{tabular}

Values in parenthesis are for the highest resolution shell 
Table 2. $M t \mathrm{PknB}_{\mathrm{CD}}$ catalytic domain and $M s \mathrm{KGD}_{\Delta 360}$ binding of different $M s \mathrm{GarA}$ point mutants. Values represent $\mathrm{KD} \pm \mathrm{SE}$ from a representative experiment (fig. S8) out of 3 or more independent experiments.

\begin{tabular}{|l|c|c|}
\hline GarA & KGD $K_{D}(\mu \mathrm{M})$ & PknB $_{\text {CD }} K_{D}(\mu \mathrm{M})$ \\
\hline Wild-type & $1.92 \pm 0.15$ & $12.2 \pm 1.0$ \\
R62A & n.d. & $14.7 \pm 1.5$ \\
S95A & $1.89 \pm 0.11$ & n.d. \\
K141E & n.d. & $10.8 \pm 0.8$ \\
R143A & n.d. & $12.4 \pm 1.1$ \\
\hline
\end{tabular}

n.d.: not determined (no reliable fit) 
A
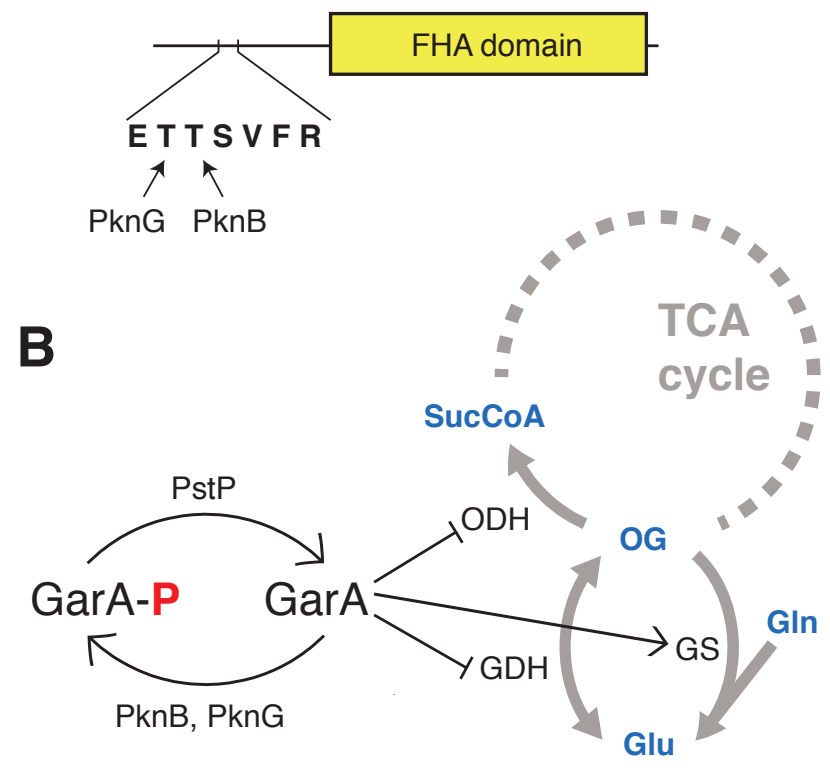

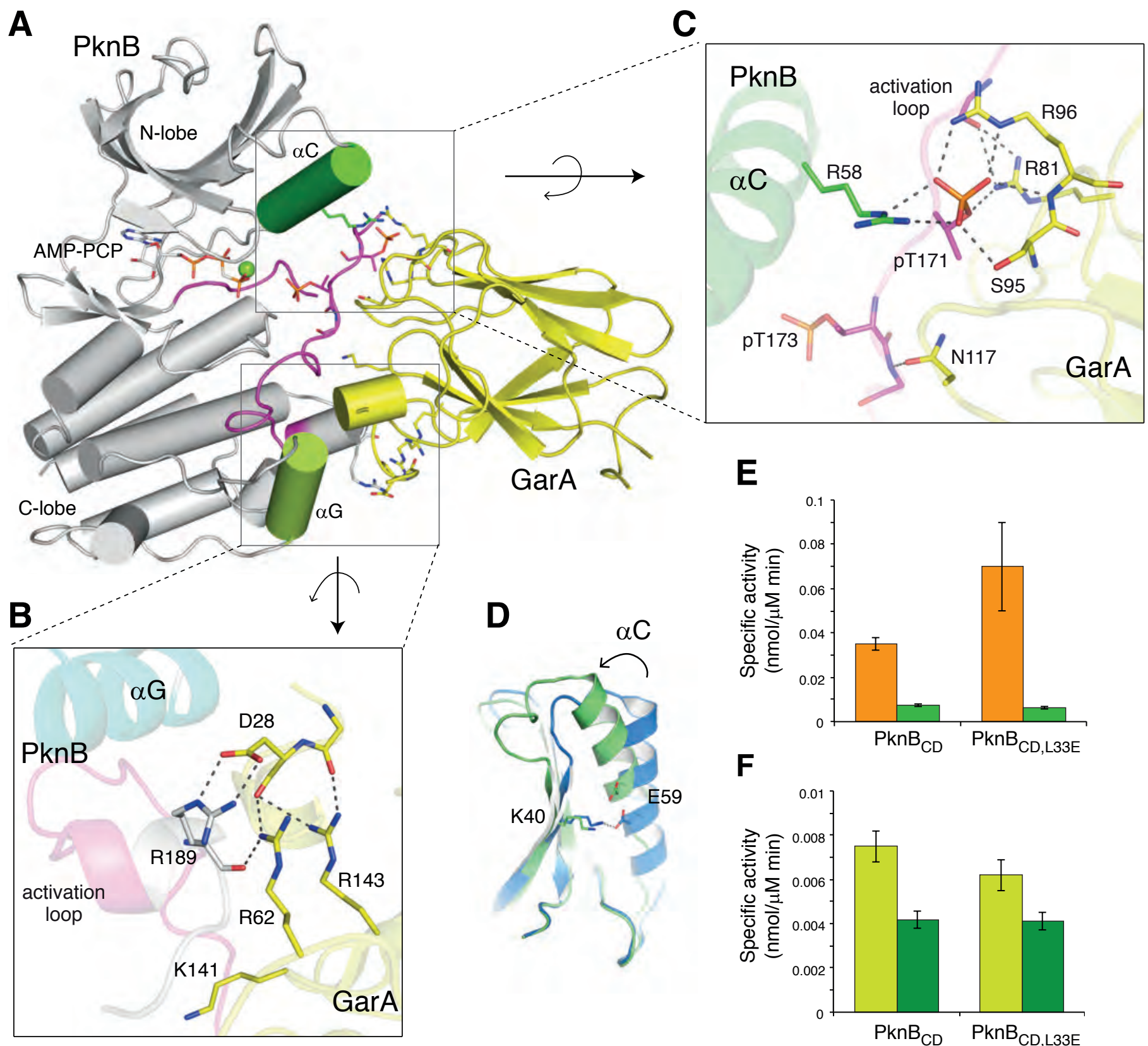

E

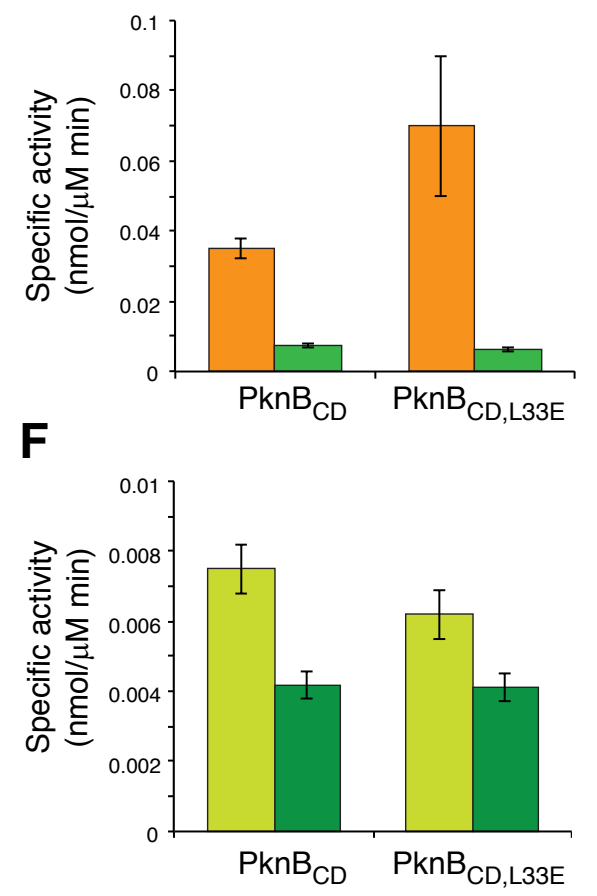




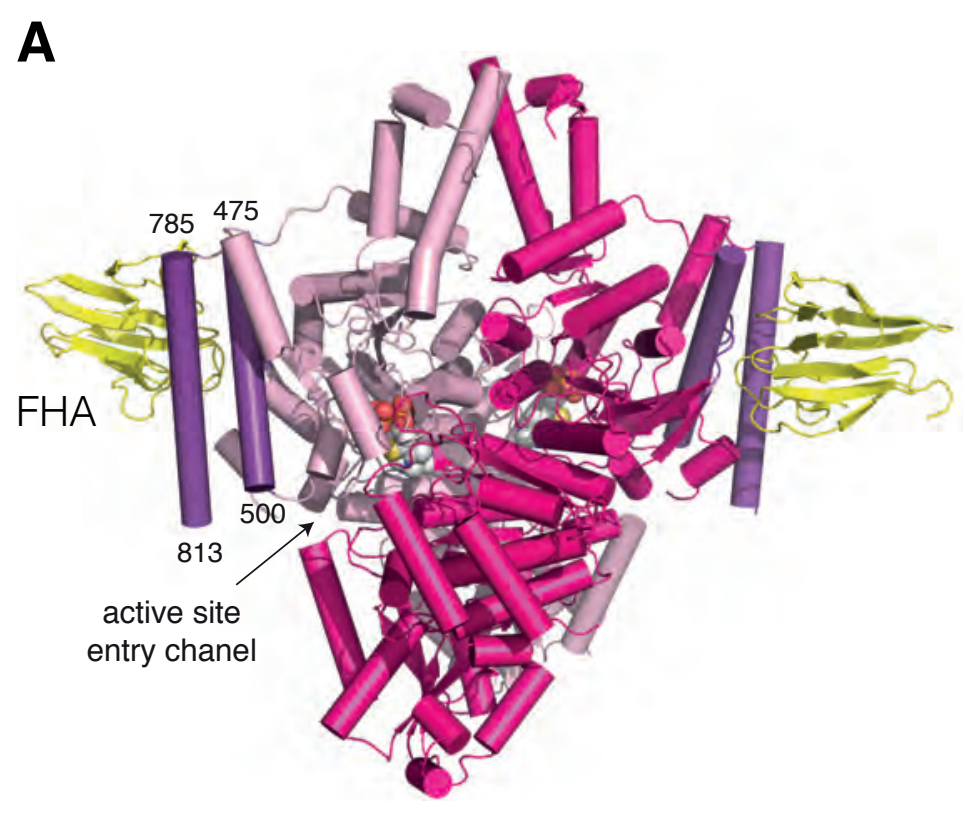

C

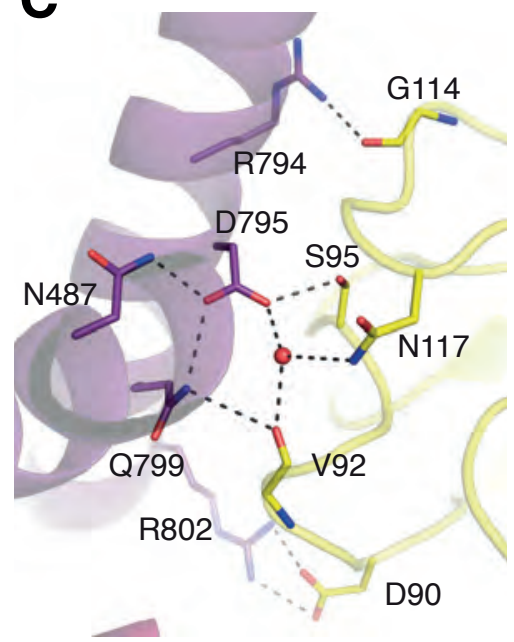

D
B
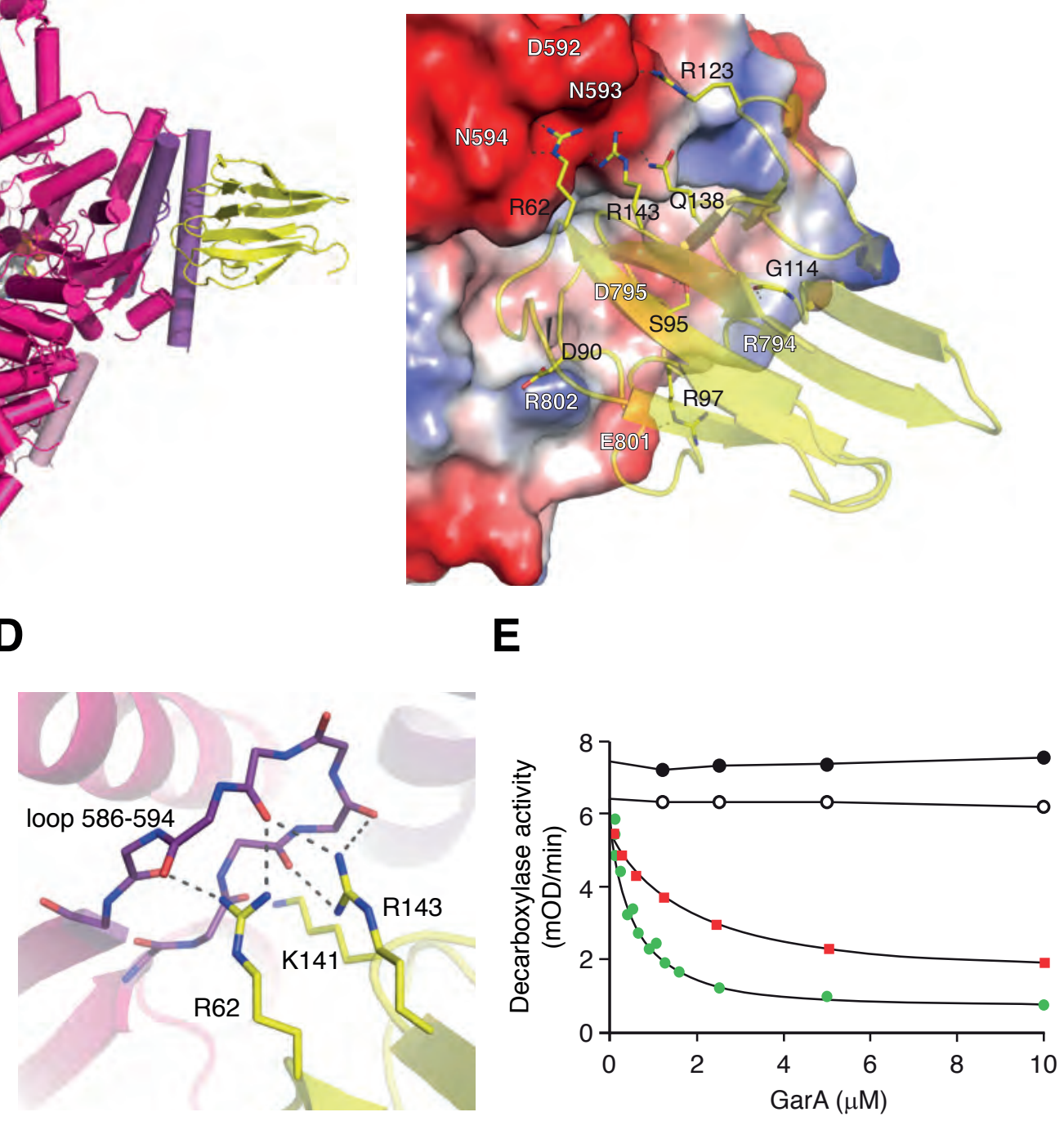

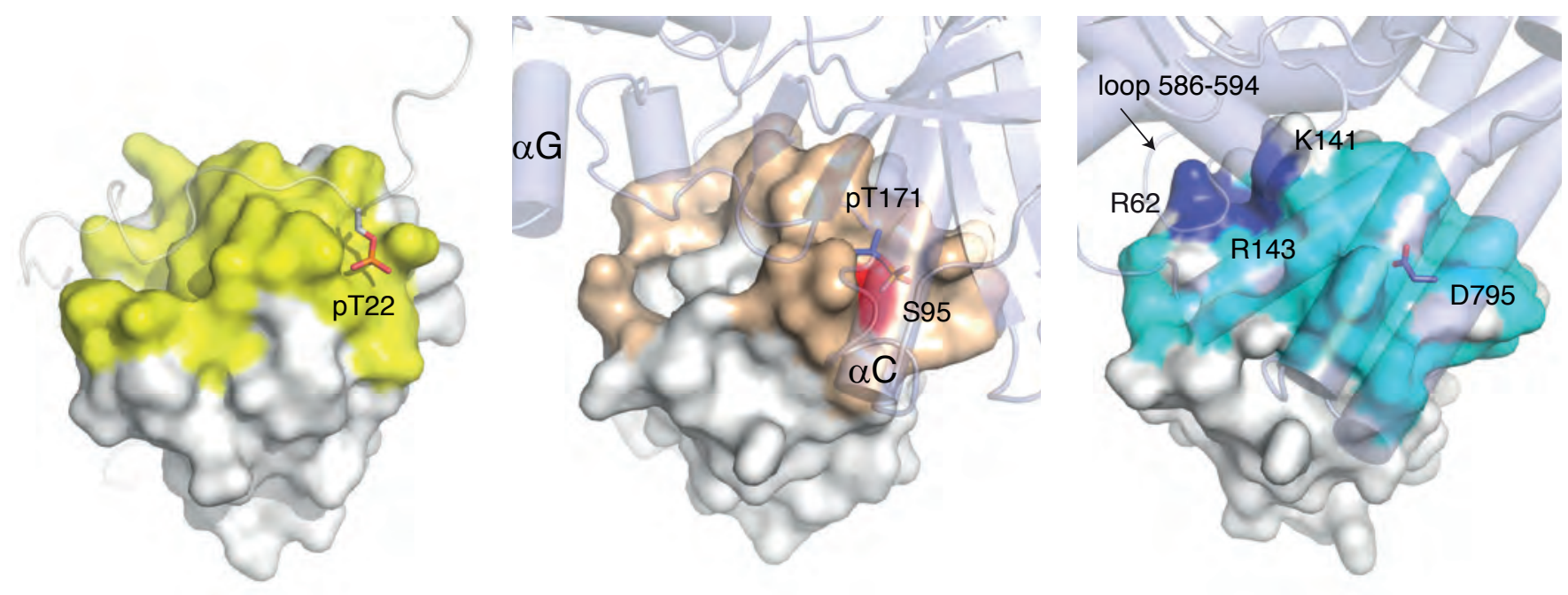

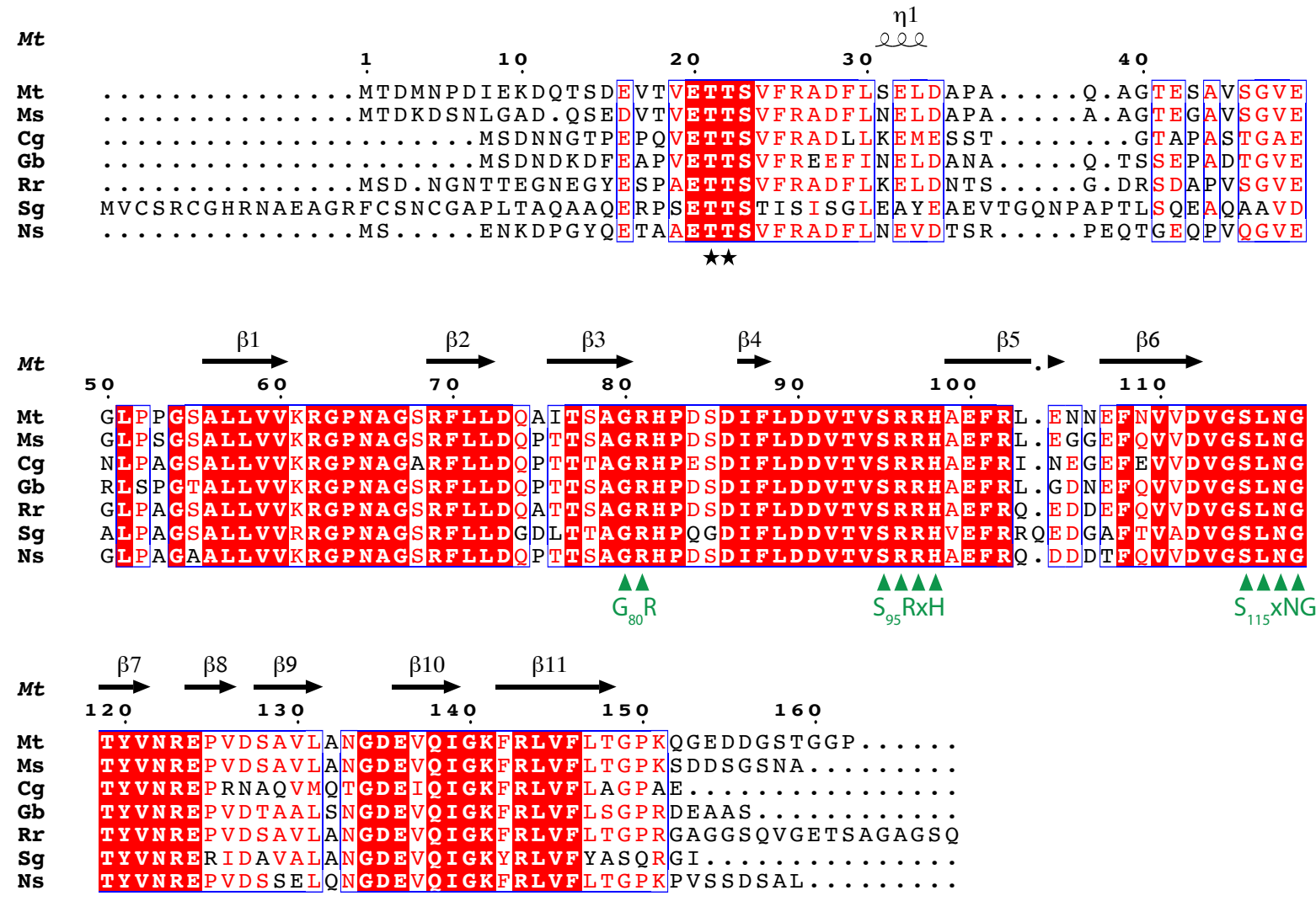

Fig. S1. Conserved amino acid sequences of GarA homologues in selected Actinobacteria. The secondary structure elements of the M. tuberculosis GarA structure are indicated above the respective sequence. The phosphorylation sites within the ETTSVFR motif (stars), as well as the three conserved motifs in FHA domains (green) are shown under the alignment. Mt, Mycobacterium tuberculosis; Ms, Mycobacterium smegmatis; Cg, Corynebacterium glutamicum (OdhI); Gb, Gordonia bronchialis; Rr, Rhodococcus rhodnii; Sg, Streptomyces griseus; Ns, Nocardia seriolae. 


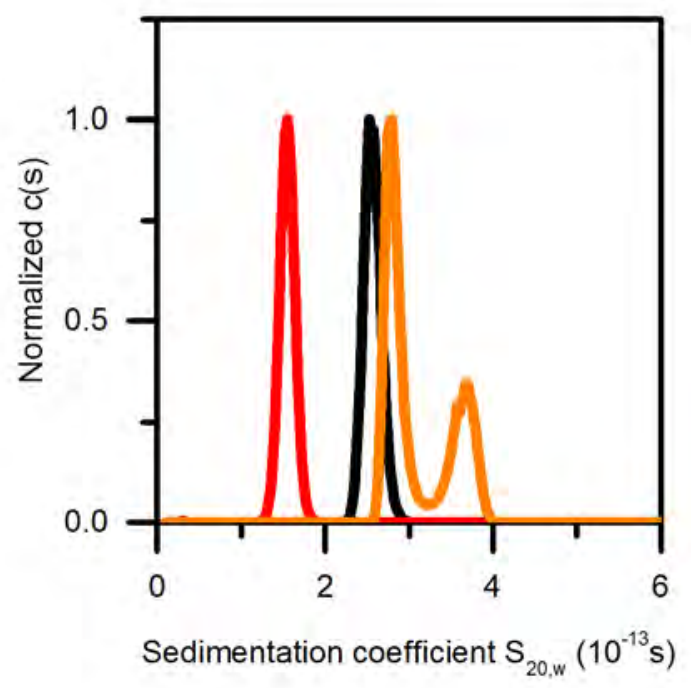

Fig. S2. Continuous sedimentation coefficient distribution analysis of the PknB $\mathbf{B}_{\mathrm{CD}}-\mathrm{Gar} \mathrm{A}$ complex. PknB (black curve) behaves as a monomer at $\sim 1 \mathrm{mg} / \mathrm{ml}$ in solution, with a sedimentation coefficient of $2.6 \pm 0.1 \mathrm{~S}$ and a frictional ratio of 1.3. GarA (red) also behaves as a monomer at the same concentration, with a sedimentation coefficient of $1.6 \pm 0.1 \mathrm{~S}$ and a frictional ratio of 1.4. After mixing the two proteins (orange), two species were observed: one with a sedimentation coefficient of $2.8 \pm 0.1 \mathrm{~S}$ (corresponding to excess monomeric $\mathrm{PknB}_{\mathrm{CD}}$ ), and the other with a sedimentation coefficient of $3.6 \pm 0.1 \mathrm{~S}$, corresponding to a $\mathrm{PknB}_{\mathrm{CD}}-\mathrm{Gar} \mathrm{A}$ 1:1 heterodimer. The observed sedimentation values of $\mathrm{PknB}_{\mathrm{CD}}$ and GarA match those calculated by hydrodynamic modelling of the crystallographic coordinates. The figure shows a representative experiment out of 3 independent replicates. 


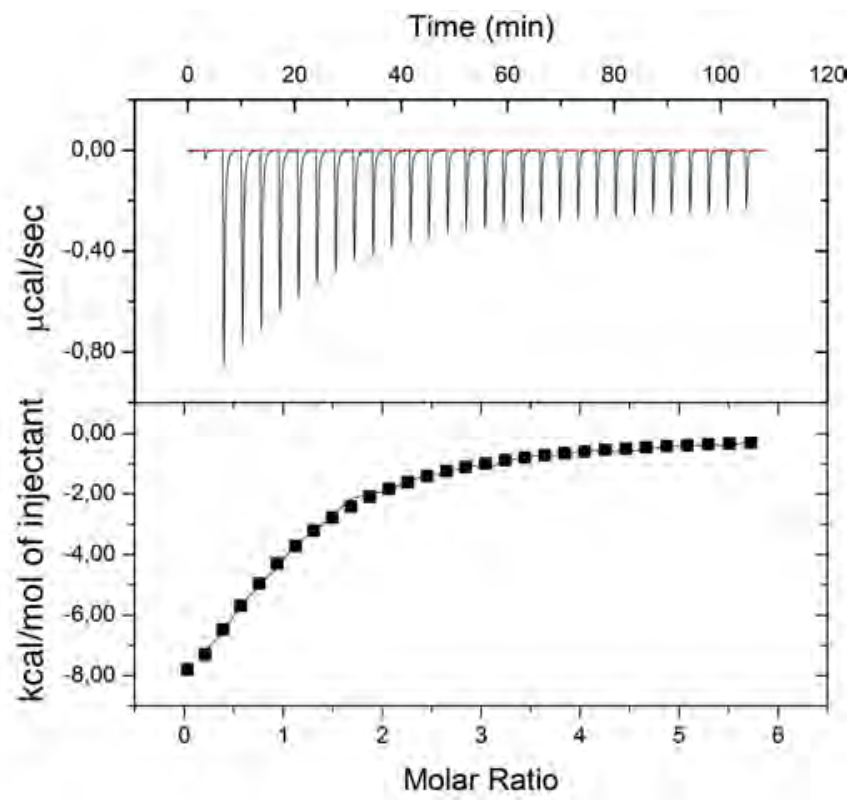

Fig. S3. Isothermal titration calorimetry (ITC) characterization of the interaction between autophosphorylated PknB ${ }_{C D}$ and GarA. The figure shows representative ITC data (out of 3 or more independent experiments), from which the parameters of the reaction were estimated. $\mathrm{PknB}_{\mathrm{CD}}$ binds GarA with a $K_{d}$ of $8 \mu \mathrm{M}$ in an enthalpy-driven reaction (stoichiometry $(\mathrm{N})=0.9 \pm 0.1, \Delta H=-14.9 \pm 0.9 \mathrm{kcal} / \mathrm{mol}, T \Delta S=-8.2 \pm 0.7 \mathrm{kcal} / \mathrm{mol})$. 

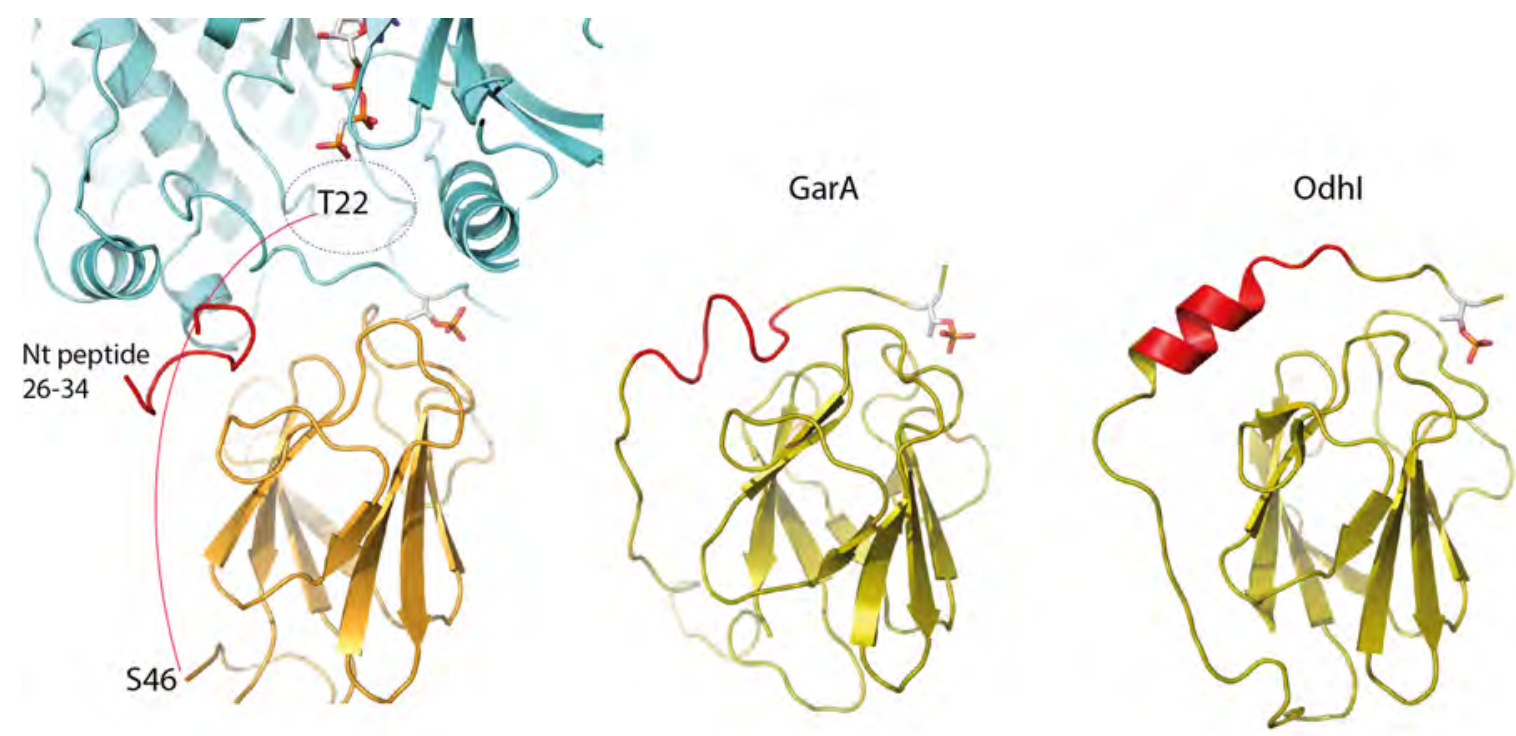

Fig. S4. The N-terminal GarA extension occupies a similar position in different GarA structures. GarA residues 26-34 (shown in red) interacts with the same region of the FHA domain in the $\mathrm{PknB}_{\mathrm{CD}}$-GarA complex (left panel), autoinhibited M. tuberculosis GarA ((13), center panel) and autoinhibited C. glutamicum OdhI ((12), right panel). This position would be compatible with occupation of the active site by the phosphorylation target $\mathrm{Thr}^{22}$, assuming an extended conformation of the N-terminus of GarA (red arc in left panel). 


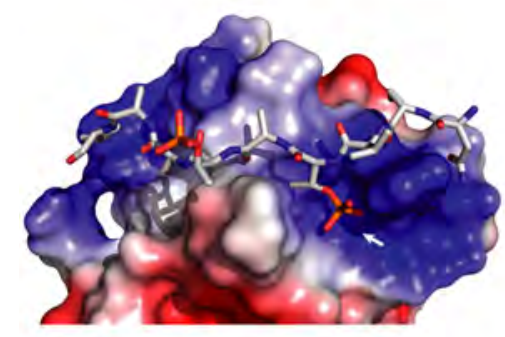

GarA

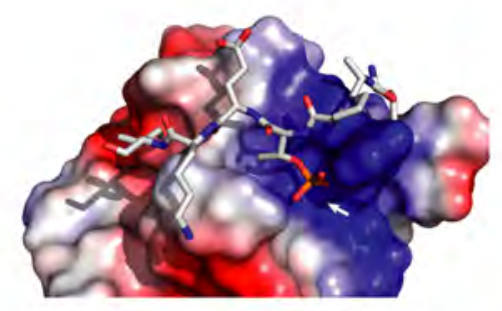

FhaA

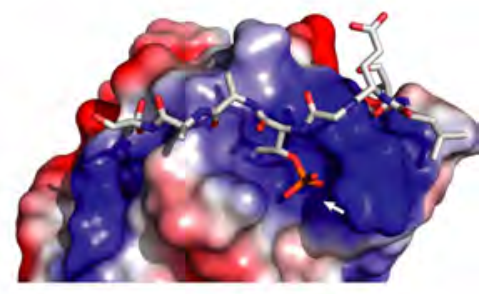

EmbR

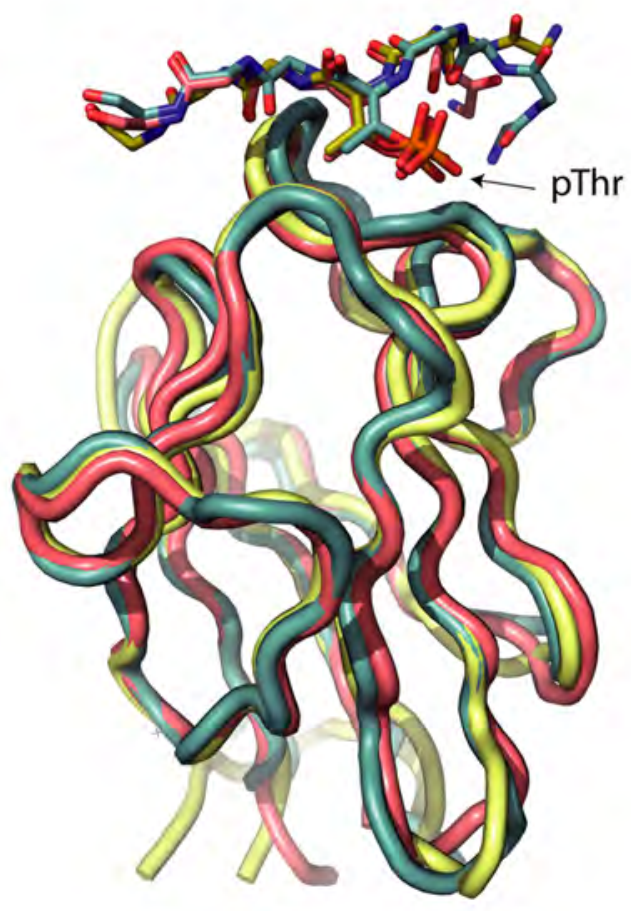

Fig. S5. Conserved mode of phosphopeptide recognition in different $M$. tuberculosis FHA domains. The top panel shows the structures of the GarA FHA domain in complex with the PknB activation loop, FhaA in complex with phosphopeptide (64), and the EmbR FHA domain in complex with a non-specific phosphopeptide (65). The electrostatic surface of the FHA domain in all cases is color-coded from acidic (red) to basic (blue) and the phosphopeptide is shown in stick representation. A white arrow indicates the position of the phosphothreonine side-chain. The bottom panel shows the superposition of the three FHA domain structures, GarA is shown in yellow, FhaA in light pink and EmbR in cyan. For clarity, only the phosphopeptide backbone and the pThr residues are shown. 


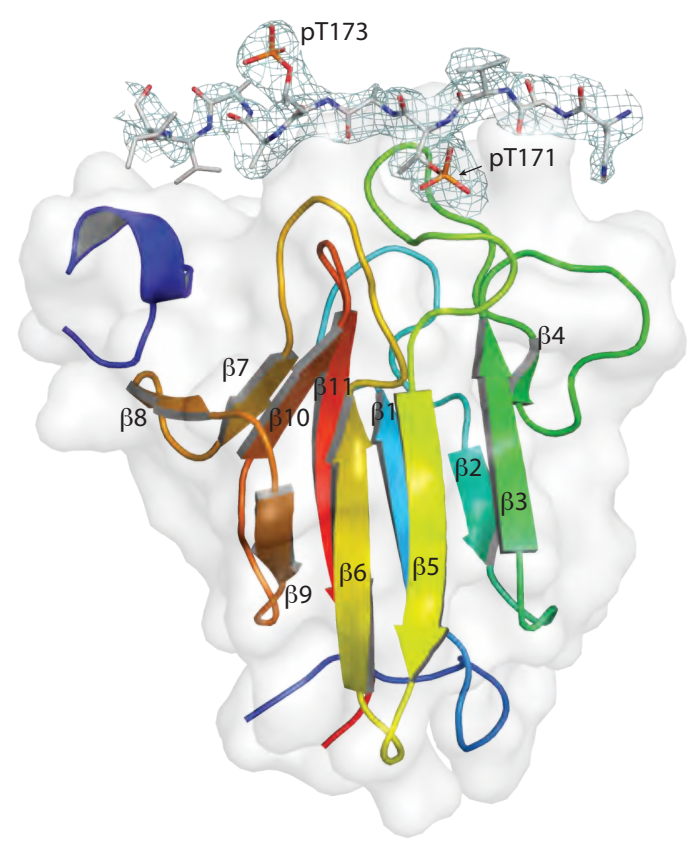

Fig. S6. Detailed structure of the PknB activation loop bound to GarA. The FHA domain is shown in cartoon and molecular surface representation, secondary structure labels ( $\beta 1$ to $\beta 11)$ correspond to those shown in Figure S1. The activation loop is shown in stick representation, the electron density $(2 \mathrm{mFo}-\mathrm{Fc})$ map is contoured at $1.0 \sigma$ and the two $\mathrm{pThr}$ residues are labelled. 


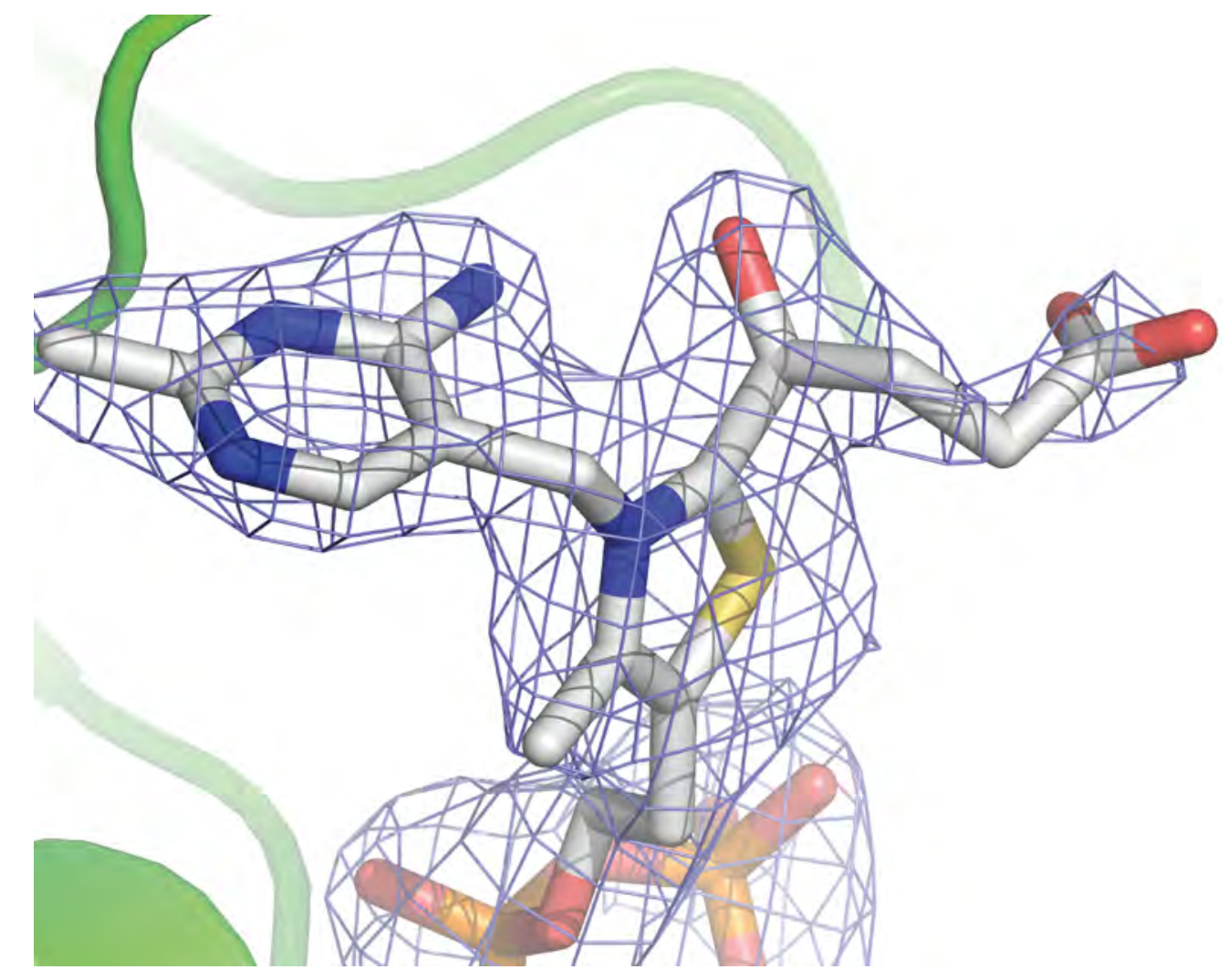

Fig. S7. Formation of the enamine-ThDP covalent adduct in the presence of GarA. The electron density $(2 \mathrm{mFo}-\mathrm{Fc})$ map contoured at $1.0 \sigma$ demonstrating the formation of the covalent intermediate in crystals of KGD-GarA complex upon soaking with 2-oxoglutarate. 

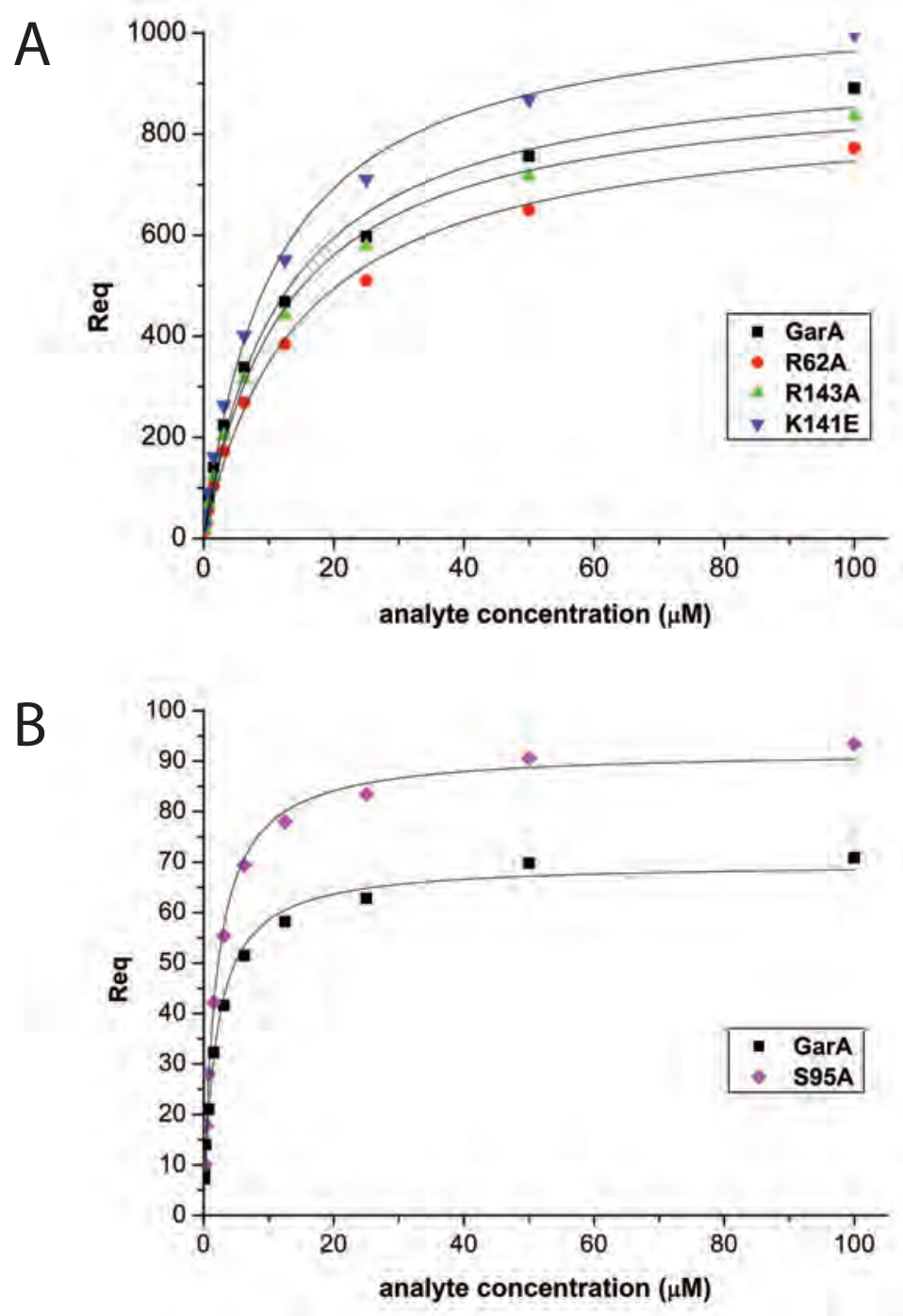

Fig. S8. Surface plasmon resonance (SPR) studies of protein-protein interactions. The plots show representative SPR responses at the steady state of immobilized $\mathrm{PknB}_{\mathrm{CD}}(\mathbf{A})$ and KGD (B) versus different concentrations of the analyte (wild-type $M s$ GarA or the indicated point mutants). The derived apparent equilibrium dissociation constants are given in Table 2, where the values represent the $\mathrm{Kd} \pm \mathrm{SEM}$ from a representative experiment out of 3 or more independent replicates. 